This PDF is a selection from an out-of-print volume from the National Bureau of Economic Research

Volume Title: Coordination and Information: Historical Perspectives on the Organization of Enterprise

Volume Author/Editor: Naomi R. Lamoreaux and Daniel M.G. Raff, Editors

Volume Publisher: University of Chicago Press

Volume ISBN: 0-226-46820-8

Volume URL: http://www.nber.org/books/lamo95-1

Conference Date: October 23-24, 1992

Publication Date: January 1995

Chapter Title: The Costs of Rejecting Universal Banking: American Finance in the German Mirror, 1870-1914

Chapter Author: Charles Calomiris

Chapter URL: http://www.nber.org/chapters/c8756

Chapter pages in book: (p. 257 - 322) 


\title{
The Costs of Rejecting Universal Banking: American Finance in the German Mirror, $1870-1914$
}

\author{
Charles W. Calomiris
}

\subsection{Introduction}

The American financial system has been an outlier internationally in virtually every important respect for the past century. It has been the most geographically fragmented and the most susceptible to financial crises (Calomiris and Gorton 1991; Calomiris 1993). It has been among the most restrictive of combinations of financial services within intermediaries, although in recent years some of these restrictions have begun to be relaxed (Kaufman and Mote 1989, 1990). The American system has also been the most persistently innovative financial system in the world. Often, important innovations have been induced by regulatory restrictions that raised the cost of finance under preexisting financial technology.

These observations are commonplace. Other unusual aspects of American financial history have received less attention, including the relative lack of bank involvement in industrial finance, the heavy reliance on corporate bonds as a means of finance, the high costs of securities underwriting, and the high cost of capital in American industry.

The main goal of this paper is to weave these peculiar features of the American system into a single interpretive tapestry. The central argument of the paper is that regulatory limitations on the scale and scope of banking in America

Charles W. Calomiris is associate professor of finance at the University of Illinois at UrbanaChampaign and a faculty research fellow of the National Bureau of Economic Research.

The author thanks Henning Bohn, Nancy Calomiris, Marco Da Rin, Barry Eichengreen, John James, Charles Kindleberger, Naomi Lamoreaux, Daniel Raff, Carlos Ramirez, Jay Ritter, Kenneth Snowden, Peter Temin, Richard Tilly, Lawrence White, seminar participants at Brandeis University, participants at the NBER Conference on Financial Institutions and Macroeconomic Stability, and participants at the NBER Conference on Microeconomic History for helpful suggestions. Jurgen Wiesmann, Susanne Hellmann, and Sandra Gerling provided invaluable assistance as translators. 
hampered financial coordination and substantially increased the cost of capital for industrialization, particularly in the period of the growth of large-scale industrial enterprises prior to World War I. This may seem a strange claim in light of American growth and financial innovativeness. The claim is not that America failed to grow and prosper, but that large-scale industrial investment was stunted relative to its potential by a faulty financial system.

To gauge the costs of American banking regulation, I compare and contrast the American and German financial systems. Rapid industrial growth in new industries and the increasing importance of large-scale enterprises are common features of the German and American experience in the pre-World War I era. The second industrial revolution witnessed rapid growth in industries that exploited new technological breakthroughs and produced entirely new products. The scale of firms was much larger than during earlier episodes of industrial expansion. Large-scale production of new products using new technologies created unprecedented challenges for the financial system. Large-scale production implied greater reliance on external funding, and the novelty of the products and techniques made it especially difficult for uninformed "outsiders" with available funds to judge the merits of the various investment opportunities. The ability of the financial system to mobilize and direct large amounts of funds into new firms was a prerequisite to rapid industrialization.

The means of financing industrial expansion during this period in the United States and Germany were quite different. The German universal banks (Kreditbanken)-sometimes referred to as the joint-stock or credit banks - were large-scale, externally financed, limited-liability banks. These banks operated nationwide branching networks and provided an unrestricted range of services, including lending, underwriting, trust services, and deposit taking. They held and underwrote securities issued by clients and made conventional loans for industrial purposes. They maintained close ties with the firms they financed and exerted control over corporate decision making in their combined role as lenders, stockholders, trustees of stock portfolios, and members of boards of directors.

The American banking system, in contrast, was shaped by restrictions on branching and consolidation that protected unit (single-office) banks. ${ }^{1}$ The fragmentation of commercial banking limited American banks' involvement in supplying credit to large-scale firms. Over the nineteenth century, as industrial firm size grew, the role of banks as suppliers of industrial credit waned, and commercial banks focused increasingly on financing commerce (Lamoreaux 1994). Private bankers operating partnerships (also known as investment bankers) filled the gap in American finance, but because they had limited resources, they relied on underwriting syndicates, funded in a decentralized way by an elaborate network of commercial banks, trust companies, and brokers,

1. Direct restrictions on the types of activities banks could finance-notably, attempts to confine bank lending to the financing of commerce, which is often referred to as the "real bills doctrine"appear not to have been a binding constraint on bank lending activities (Lamoreaux 1994). 
to raise funds for the firms they financed. Like universal bankers in Germany, investment bankers established methods for monitoring and controlling corporate management of the firms they financed.

Clearly, these are two very different ways of coordinating the flow of funds from savers to investors. But did these differences matter? In section 8.2 , I review general theoretical and empirical perspectives that suggest why they may have mattered. Here the review is selective, and serves to introduce concepts that will be emphasized in section 8.3's detailed discussion of the German and American financial systems and economies. Section 8.3 compares and contrasts the German and American experiences, argues that the various differences between them are mutually consistent, and points to evidence of higher costs of industrial finance in the United States. That section closes with a brief historical review of the different evolution of financial regulations and institutions in the two countries.

Section 8.4 offers some conjectures on why inefficient restrictions on banking have persisted in the United States. Limitations on branching and restrictions on joint production of financial services did not disappear as their costs became apparent. Indeed, the Great Depression saw an increase in restrictions, most notably the separation of commercial and investment banking, many new restrictions on securities transactions, a reversal of direction in the regulatory trend toward branching and consolidation of the 1920s, and the subsidization of unit banking by the creation of federal deposit insurance. Political considerations, as well as endogenous changes in financial technology that lowered the costs of regulation, may help to explain persistently poor banking regulation in the United States.

\subsection{General Perspectives on Universal Banking}

This section provides an overview of general theoretical and empirical perspectives on universal banking, which will serve as a basis for the discussion of section 8.3. I begin with a discussion of the role of various intermediaries and contracting arrangements for mitigating financing costs. Second, I argue that the form of financial instrument and the intermediation arrangement chosen by a firm reflect its place in the financial "pecking order," which is largely determined by the stage it has reached in its financial "life cycle." Third, I examine the role played by universal banking in reducing firm financing costs. Universal banking is defined as a combination of activities performed by banks, including deposit taking, trust services, direct lending, equity holding, and underwriting. Informational economies account for economies of scope among the three forms of intermediary financing of firms (lending, equity holding, and underwriting). These economies of scope are driven by considerations of time consistency, the reusability of information over the firm's life cycle, and improvements in the quality of signals generated by underwriters. Fourth, I consider the effect of restrictions on bank branching on the efficiency 
of universal banking. The benefits of universal banking are enhanced in a system that allows banks to branch. Direct access to sources of funds through deposit and trust accounts reduces the costs of marketing securities by facilitating the flow of information and limiting the number of layers of securities transactions.

This four-part summary of the economics of universal banking places universal banking in the context of theoretical literature on the role of banks and the financing structure of corporations. The changing needs of corporations over time correspond to different financial products produced by the universal bank. The advantages of a long-term relationship between a firm and an intermediary are best achieved by allowing the intermediary to perform a variety of tasks. The advantages of universal banking are best achieved in the context of large-scale banking, where transactions and information costs of syndications are minimized.

The theoretical discussion closes by linking these arguments to others made in the existing literature, both for and against universal banking. My emphasis on benefits of universal banking from reductions in corporate finance costs is also related to the question of portfolio diversification benefits under universal banking. Much of the recent policy debate over universal banking in the United States has focused on potential advantages from diversification from allowing commercial banks broader powers. A weakness of some of these studies has been the implicit assumption that available market assets are invariant to the establishment of universal banking. Potential benefits from diversification depend on the effect universal banks have on the feasible set of externally financed investments. If universal banking reduces corporate finance costs, then it enlarges the set of investments available to "outsiders."

Common theoretical arguments against universal banking are considered in light of theory and history. These include destabilization of the financial system, conflicts of interest, and inefficiency from lack of competition in banking or in industry. Theory and history support the view that universal banking is a stabilizing influence on banking. Furthermore, potential problems of conflict of interest can be overcome if universal banks are allowed to hold or manage equity as well as to underwrite and lend. Finally, while bank concentration and long-term links between firms and their banks may encourage lack of competition among banks or firms, Germany's universal banking system had many observable advantages, and was not a necessary condition for the formation of industrial cartels.

\subsubsection{The Roles of Financial Intermediaries}

Financing investment is fundamentally a problem of coordination. Savers and investors need a low-cost means to transact. Of course, ultimate savers and investors virtually never meet. Rather, each deals with an intermediary, and often ultimate savers and investors do not use the same intermediary. In many 
transactions, complex hierarchies of intermediation may be employed. For example, many individuals own securities primarily through pension funds. Pension-fund managers might purchase securities through local bankers or dealers, who in turn may be marketing these securities for an investment banking syndicate formed and financed by a small group of banks, and managed by a lead investment bank who negotiates the deal with the issuing firm.

The links separating the individual saver and the firm issuing the security in this case are many, and involve substantial costs. These costs can be divided usefully into two categories: costs of information collection and transmittalthat is, costs of creating and enforcing mechanisms that lead to credible monitoring of firms and revelation of the true state of firm finances-and physical transactions costs - costs associated with legal and accounting paperwork, and with physically distributing securities to ultimate holders.

Recent contributions to the literature in banking and corporate finance have drawn attention to the ways various institutional arrangements can economize on such costs. For example, the costs to investment banking syndicates of collecting information about the proper pricing of new issues may be affected by the mechanism chosen for the initial marketing of the securities. Rationing of issues to a select group of securities purchasers who have repeated contact with the investment banking house may encourage truthful revelation of information about the value of the securities by those purchasers prior to the issue. Benveniste and Spindt (1989) argue that this beneficial revelation effect explains various otherwise puzzling features of the marketing and pricing of initial public offerings (IPOs). More generally, investment banks are valuable to the economy because they provide a low-cost means of generating and disseminating credible information about firms' characteristics, which benefits both securities issuers and purchasers in deciding on the form and price of the security used to finance an investment.

The recent literature on banking also views commercial banks as solving problems that arise from physical transactions costs and information asymmetry, and sees the form of intermediaries' contracts as a key determinant of the cost of finance. Banks economize on physical costs of transacting (clearing payments, liquidating insolvent firms), costs of generating information (monitoring firms' actions and outcomes), and costs of enforcing contractual compliance on the part of firms and bankers (disciplining borrowers and protecting against improper behavior by the banker at the expense of those funding the bank).

Models of banking stress the economies of concentrating funds in banks and appointing the banker as the "delegated monitor" of bank borrowers (Campbell and Kracaw 1980; Diamond 1984; Calomiris and Kahn 1991; Calomiris, Kahn, and Krasa 1992). Banking arrangements can avoid duplication in monitoring bank borrowers and thus reduce banking costs. Enforcement of contracts (monitoring and discipline) is also less costly if a single agent with proper incentives can specialize in the task. 
Empirical evidence on the characteristics of firms choosing banks as financing sources confirms the view that banks specialize in performing ongoing monitoring and contractual enforcement for firms whose access to outside funding otherwise would be limited (Butters and Lintner 1945; Fazzari, Hubbard, and Petersen 1989; James and Wier 1988, 1990; Mackie-Mason 1990). Other firms-older, better-known firms - have access to securities markets on better terms and can avoid the costs of bank finance. These firms typically still use intermediaries (like investment banks) to assist them in determining what types of securities to issue and in credibly signaling the value of their securities (Benveniste and Spindt 1989; Ramakrishnan and Thakor 1984), but they avoid at least some of the ongoing costs of bank finance. Costs of bank finance include regulatory costs (like reserve requirements), monitoring costs, and rents the bank may extract from firms it finances by virtue of its possession of private information, as in Rajan 1992a.

Empirical studies of the effects of bank lending decisions on the prices of existing securities or bank borrowers also provide evidence of the role of banks as "insiders" with respect to information relevant for valuing claims on firms to which they lend. Announcing financing arrangements between banks and firms increases firms' stock prices (James 1987; James and Wier 1988). Bank participation in working out corporate distress increases the value of distressed firms' stock (Gilson, John, and Lang 1990), especially when banks are willing to take a junior position in the firm (Brown, James, and Mooradian 1991). Japanese firms with close, long-term banking relationships are better able to maintain investment levels than other firms during episodes of financial distress (Hoshi, Kashyap, and Scharfstein 1990a, 1990b).

\subsubsection{The Financial "Pecking Order" and the "Life Cycle" of Firms}

The growing theoretical literature in corporate finance focuses on how particular financing arrangements mitigate some costs at the expense of others. In some cases, using an investment bank may be desirable because it provides a low-cost means of signaling the value of securities. In other cases, bank loans may be the appropriate financing vehicle, possibly because of banks' low costs of managing financial distress or of monitoring managers' actions and enhancing corporate control.

The new "information-based" approach to corporate finance revolves around the financial "pecking order"--a continuum of financing instruments defined according to the elasticity of their cost with respect to problems of asymmetric information (Myers 1984; Myers and Majluf 1984; Diamond 1991). Firms progress up the pecking order of finance as they mature. Firms just starting out may be forced to rely exclusively on retained earnings and the wealth of insiders. After a successful beginning, the firm can rely on "inside debt" in the form of bank loans. The bank spends resources to monitor the firm, and protects itself against "lemons" problems by holding a debt claim on 
the firm. ${ }^{2}$ As the firm matures and develops a track record, its financing will change. Informed intermediaries will be willing to take equity positions in the firm (as in the venture capital market), which will reduce the leverage of the firm and its exposure to financial distress, and provide a positive signal to outside investors. Outside finance through securities may initially take the form of senior instruments with protective covenants (e.g., bonds). Later, firms will graduate to issuing preferred and common stock on the open market to outsiders, using underwriters as a means for providing credible signals of the firm's value to outsiders.

The maturity of debt instruments chosen can reflect a tradeoff between the information and transactions costs of finance. Short-term debt mitigates incentive problems between banks and firms. As Jensen and Meckling (1976, 33437) show, debt contracts create a potential agency problem known as the "asset substitution effect." Once debt contracts are entered into, managers with an equity interest in the firm may have an incentive to take on greater risk, because they are only concerned with expanding the upper tail of the asset returns distribution. Short-term debt can be useful as a means to restrict such risk taking. Firms that increase risk face the threat that their loans will not be rolled over, or will be rolled over only at a higher interest rate. If lenders keep debt shortterm and monitor borrowers' actions, borrowers will find little benefit in increasing risk, so long as the threat of the bank's rollover response is credible (e.g., see Pennacchi 1983; Gorton and Kahn 1992). Similarly, bank-loan contracts typically allow acceleration of the maturity of debt when the firm's position deteriorates. This right of acceleration is particularly powerful in restricting borrower risk taking when combined with compensating balance requirements (which force firms to hold their checking accounts in the bank) and the option of deposit setoff (bank seizure of deposits), as Garber and Weisbrod (1991) argue.

Despite the advantages of short-term debt in protecting lenders and encouraging proper behavior by borrowers, short-term debt has higher transactions

2. Given the general predominance of debt finance, particularly in banking, recent contracting models try to explain the optimality of debt. Debt claims are often a desirable means of finance when claimants are relatively uninformed about firm opportunities or outcomes, or when outcomes are difficult to demonstrate to a third party. As Myers and Majluf (1984) show, in a world where firms" opportunities are unobservable ex ante, debt suffers less of a "lemons premium" than equity because the payoffs to debt depend less on the unobservable information. Townsend (1979), Diamond (1984), Gale and Hellwig (1985), Williamson (1986), and others have argued that costs of ex post monitoring and third-party verification favor the use of debt contracts. Lacker (199l) shows that debt is especially useful in these environments as a means to penalize firms by threatening to take collateralized assets that have special value to the firms' operators.

These arguments for the optimality of debt contracting may help explain the reliance by banks on deposits and banknotes as the primary means of "outsider" financing of bank activities historically (as argued above), and the use of debt as the primary means of "outsider" finance of many corporations. But these arguments do not suggest that bank financing of firms will always, or even mainly, occur in the form of debt. Indeed, the pecking-order theory of corporate finance-which emphasizes the role of debt as an optimal means of financing outsiders' contributions to the firmsuggests advantages from insiders' avoidance of debt, as argued below. 
costs than long-term debt. The costs of renegotiation and rollover are especially large for nonbank debt, which must be physically redeemed and reissued to a widely dispersed group of creditors. ${ }^{3}$ For example, the costs of issuing bonds (costs charged for paperwork and for fees to the investment banking syndicate marketing the bonds) averaged 6 percent of the size of the issue in the United States during 1925-29 (Securities and Exchange Commission 1940, 10-11). If the maturity of these bonds had been, say, one year rather than the actual fifteen-to-twenty-year average maturity (Hickman 1960, 152), this would have entailed a significant increase in the cost of funds. Thus, shortterm debts of firms typically take the form of bank loans (with low rollover costs) or short-term trade credit. ${ }^{4}$

In summary, banks, investment banks, and other intermediaries can be seen as "optimal mechanisms" for connecting particular groups of savers and investors in a world of costly transactions and asymmetric information. Informational characteristics of firms (the availability of a track record, the costs to outsiders of monitoring and controlling activities of the firm) are important determinants of whether firms choose to finance themselves with securities issues or with bank lending, and of the form and maturity of the financing instrument. This approach emphasizes the importance of financing through banks in the early stages of the life cycle of the firm, and sees other forms of intermediation (investment banking) as depending on earlier information creation by the firm's track record with inside lenders. Choice variables for minimizing financing costs include the intermediation technology used, the forms of the claims issued (e.g., debt or equity) by firms and intermediaries, their maturity, covenants on behavior and options granted to holders or issuers of claims on firms or banks, liquidation rules, allocation of voting authority, agreements that ensure a long-term relationship between or among contracting parties (and thereby solve problems of time inconsistency), and the voluntary formation of coalitions (of banks, investment banks, or informed IPO purchasers), which regulate the behavior of members. ${ }^{5}$

3. Another reason why banks may be in a better position to offer short-term debt is suggested in recent work by Diamond (1992). He argues that short-term debt can be costly when held by uninformed lenders because they may be too quick to liquidate a solvent, but illiquid, firm. One could argue that, if banks are better informed about firms, they will be able to reap the disciplinary advantages of short-term debt without creating losses through excessive liquidations.

4. In addition to bank loans, the United States developed an important innovation in commercial and industrial finance, which became known as the commercial paper market. For reasons related to its fragmented banking system, bankers' acceptances and foreign bills of exchange never reached the level of importance in the United States that they did elsewhere (Calomiris 1993). The commercial paper market developed as a means for banks to transfer their lowest-risk customers to other intermediaries, to take advantage of lower costs of finance in other locations. The commercial paper market was a unique feature of the American financial system, which grew substantially in importance during the last quarter of the nineteenth century.

5. An important contributor to minimizing finance costs has been coalitions of banks, whose function includes cooperation in underwriting networks, interbank correspondent relations, cost- 


\subsubsection{The Advantages of Universal Banking}

The pecking-order framework implies that financing arrangements that accelerate the process of seasoning a firm and economize on the costs of information production and corporate governance can stimulate investment by reducing the costs of external finance. In this light, the main advantage of universal banking is that it encourages a long-term relationship to develop between a firm and its intermediary by allowing the intermediary to vary the form of firm financing as the firm matures, in keeping with the optimal financing arrangement, which changes over the life cycle of the firm. Initially, the intermediary lends directly to the firm. Later, it will be best for the same intermediary to underwrite the firm's securities issues (either by itself or as a leader of a syndicate of universal banks). Underwriting will require that the bank be allowed to own (and act as trustee for) shares of the firm. Without the flexibility to vary the form of the bank-firm relationship, relationships between firms and banks are unlikely to persist over the firm's life cycle.

By "long-term" I mean that the firm and bank have a credible implicit contract to continue to do business in the future. The firm cannot switch banks costlessly. The advantage of a credible long-term relationship is that it encourages banks to lend to firms on favorable terms in anticipation of a continuing relationship. The costs of gathering information about a firm's credit risk is high for unseasoned firms, which pay for bank monitoring in the form of higher interest cost on loans. If banks can spread the cost of monitoring over many periods, this reduces the initial costs of borrowing and allows firms to pay less for credit during their early years when investment needs are high and cash flow is low. Despite the advantages of a long-term relationship for smoothing the cost of credit to firms, there is a potential "time-inconsistency" problem that makes it difficult for banks to postpone charging firms for high early monitoring costs. Firms receiving low-interest loans in their early years may opt out of the initial banking relationship once they become seasoned and have opportunities to borrow from other intermediaries. Competing intermediaries may be able to provide credit at lower cost in the later stage of the firm life cycle because the costs of monitoring the firm have fallen as the result of its observable credit history with the initial bank (James and Wier 1990). Thus, competing banks may be able to "free ride" on the initial bank's efforts.

In practice, long-term exclusivity can be enforced in two ways. First, to the extent that competing banks are unable to learn relevant information about the firm from the initial bank's lending decisions, the initial bank's investment in

effective payment clearings, and perhaps most important, coalitions for mutual protection. Such coalitions are more easily organized, managed, and self-regulated in a concentrated banking system. For discussions of several examples, see Gorton 1985, 1989; Gorton and Mullineaux 1987; Calomiris 1989, 1990, 1993; Calomiris and Kahn 1990, 1991; and Calomiris and Schweikart 1991. 
information about the firm at an early stage reduces future costs of granting credit or underwriting only for the initial bank, so the firm and bank are naturally drawn to one another for repeat business. ${ }^{6}$ Second, banks may prohibit "their" firms from doing business with other banks (Neuburger and Stokes 1974, 713). Presumably, such prohibitions would be enforced by cooperation among the banks to limit deviation from this rule. While finance historians have argued that banks in Germany and the United States were not successful in enforcing exclusivity once clients became large, well-known firms (Tilly 1992, 109), nevertheless, for a limited period of time such enforcement may have been important.

Given the benefits to borrowers from interest cost smoothing, such collusion among banks is not necessarily a bad thing. Although it may allow banks to extract rent from firms, without it the advantages of a long-term relationship may not be available to young, growing firms. Mayer (1988) cites post-World War II Japan as an example of successful elimination of information externalities among banks through credible long-term contracting, made feasible by limits on period-by-period competition among banks. Without a credible longterm relationship between firms and banks, banks may have been unwilling to pay fixed costs initially and bear risk during early stages of industrialization of infant industries.

Another important avenue for internalizing externalities for banks lending to young, growing firms is to allow banks to take equity positions in these firms. This allows banks to benefit fully from the positive signal they create when they finance firms. Also, by making banks junior claimants on the firm, equity holding provides a strong incentive for continuing diligence by the banker (Pozdena 1991). ${ }^{7}$ Equity financing has other advantages as well. It re-

6. Given the evidence of disadvantages from not creating a long-term bank relationship, or of deciding to discontinue one (Hoshi, Kashyap, and Scharfstein 1990a, 1990b; De Long 1991; Ramirez 1992), it may seem puzzling that some firms did not opt for such a close, long-term relationship. A simple example will help to fix ideas, and help one to understand why some firms may choose not to borrow from universal banks, or to discontinue borrowing eventually. Suppose that the costs to a bank at time zero of starting a relationship with a firm consist of monitoring costs, which decline over time. To be concrete, assume the initial cost to the bank is $X$, and the costs for all subsequent periods is $m$ per period. Furthermore, assume that, if the firm cannot borrow from a bank, it must rely only on retained earnings to finance investment, and that this entails a reduction in profitable investment (alternatively, one could assume the firm will borrow from nonbanks at a higher cost, reflecting a lemons premium on uninformed lending). For simplicity, assume the firm will need external funding for only 10 periods, after which its investment opportunities can be completely financed from its (larger) stream of retained earnings. The bank will charge a fee for the ten periods of $z$ per period, which includes reimbursement for $X$ and $m$ costs, and possibly additional rents extracted by the bank (if the bank has an initial information advantage over its competitors). The firm compares the value of joining the bank (the present value of firm assets if it joins the bank minus the $z$ fees), with the present value of firm assets if it does not join the bank. Firms that require a large $X$ and $m$ investment relative to the advantages they would receive from rapid access to finance through a banking relationship will prefer autarky.

7. By holding equity in the firm, the bank may also be able to exert influence over the firm's future choice of a bank to act as purchaser and underwriter of securities. Thus equity can help solve 
duces financial distress costs for firms by reducing leverage, and by concentrating ownership stakes (which reduces bargaining and coordination costs among creditors during distress). Also, in distress states, firms may need their banker to credibly signal that the firm's prospects are good to other firm creditors. A bank's willingness to exchange debt for equity in the firm during distress can be a strong signal of the bank's confidence in the firm (Brown, James, and Mooradian 1991). Several recent studies of Japanese banking have emphasized the advantages of stock ownership by banks as a means of promoting monitoring and reducing costs of financial distress. ${ }^{8}$ A final advantage of allowing equity finance is that this avoids potential conflicts of interest between the firm and its creditors. Reliance on debt can lead to an "underinvestment problem" (Myers 1977). Positive net present value (NPV) projects with relatively low risk may not be undertaken on the margin because undertaking the project generates a transfer of wealth from the firm's stockholders to its debtholders. Similarly, debt finance entices firms to substitute relatively high-risk assets for existing low-risk assets, since such substitution leads to a wealth transfer from creditors to stockholders.

These advantages from equity contracting may be offset by costs associated with equity finance. If the riskiness of firms is unobservable, those who finance firms must charge all firms the same cost of finance. For good firms, this entails a lemons premium on their cost of finance. The premium will be largest for junior securities, since their payoffs are the riskiest (Myers and Majluf 1984). Also, as Jensen and Meckling (1976) and others have stressed, if managerial effort depends on managers' stakes in the firm, or if management's objectives conflict with shareholders', then equity issues can reduce managerial incentives and encourage non-profit-maximizing behavior by management (by reducing the concentration of ownership in the firm, and hence the ability to discipline managers).

\footnotetext{
Mayer's (1988) time-inconsistency problem, in part, by allowing banks to control firm financing decisions in the future. As argued below, there is little evidence for this sort of monopoly control by banks in Germany or the United States, at least after the 1890s.

8. Sheard (1989) points out that a "main" bank's debt position in a firm often takes a junior position to other debt effectively, and is written down during financial distress to avoid bankruptcy. Thus Japanese banks' "equity" positions in firms are effectively larger than their balance-sheet statements would indicate. Kim (1992) finds that equity stakes by Japanese banks are higher for growing firms with high external finance ratios and high risk. In Japan, the incidence of bankruptcy is much lower, and the costs of bankruptcy when it does occur are also much lower, than in the U.S. Kim shows that these advantages in Japan depend on the ownership structure of firmsspecifically, the concentration of ownership in the firm (or equivalently, the proportion of the firm owned by banks). Hoshi, Kashyap, and Scharfstein (1990b) find that firms with close ties to Japanese banks suffer much lower reduction in investment levels during periods of financial distress, but they do not find an effect from bank's equity interest on the costs of financial distress once one has controlled for other characteristics of the firms' financing sources. The upshot of their findings is that there are substitute means for achieving the desirable features of inside equity, which take the form of concentrating lending in the hands of few borrowers, or allowing banks to hold junior debt positions that have equitylike features. Further support for this interpretation comes from Prowse (1992) and Hoshi, Kashyap, and Loveman (1992).
} 
Thus, reaping the advantages of equity depends on constructing mechanisms that provide adequate control over the firm's management to avoid prohibitive lemons premiums and managerial incentive problems. Bankers may sit on corporate boards of directors and exert direct control over managerial decisions. This entails large fixed costs to the bank, which may be prohibitive for small firms with uncertain prospects. Alternatively, firms could avoid equity issues and rely on debt. In this case, banks use debt covenants and shortterm debt as a disciplinary device on management. Managers who behave improperly will find their credit lines discontinued by the bank, through either the "calling" of the bank's loan or the bank's decision not to rollover its debt. As discussed below, the history of German universal banking - in which both enforcement technologies were available to banks-suggests that banks began lending to firms via protected short-term debt. Once the firm had matured and the bank had become an informed insider, both parties benefited from a conversion of short-term debt into equity finance. The transition from debt to equity finance also entailed an increased role of the bank in controlling corporate decision making through the board of directors. The life cycle of "corporate governance" arrangements with intermediaries parallels the life cycle of the firm's financial structure.

Thus, the economies of scope from a single intermediary being able to lend, hold equity, exert corporate discipline, and underwrite securities for a firm may be entirely unrelated to conventional technological economies of scope (or transactions costs) in providing these services. Rather, the main advantages of allowing a single intermediary to perform all these activities revolve around information and control economies. First, in the context of the pecking-order approach outlined above, because lending to a firm precedes underwriting in the firm's life cycle, a bank that has lent to the firm in the past will have access to private information that will reduce the costs of underwriting. Second, consistent with Mayer's (1988) emphasis on time consistency, it may be important to allow the bank to hold equity and underwrite securities for the mature firm as an efficient means for the firm to pay for earlier bank investments in information with capital gains on stock and underwriting fees at later dates when the firm's cost of funds is lower. Third, when banks take long-term positions in a firm, by lending or holding the equity of the firm, their signals as underwriters may be more credible. This is particularly true if banks are allowed to hold equity; or alternatively, if the securities they underwrite are senior to preexisting claims on the firm. ${ }^{9}$

9. It is possible that universal banking can involve a conflict of interest. Banks with existing claims on a firm might use underwriting as a means of reducing losses on their existing claims on the firm by attracting outside investors, or, conversely, banks may discourage outside investors to keep a good-risk firm to themselves. These problems can be overcome if banks are allowed to have a stake in the securities they underwrite, or if the security being underwritten is senior to the bank's existing claim on the firm. For both of these reasons, it is important to allow banks to take equity positions in firms or manage equity holdings by bank trust customcrs. 


\subsubsection{Universal Banking and Bank Concentration}

The recent literature on commercial banking has stressed advantages of allowing banks to be large. A concentrated banking system permits greater portfolio diversification of banks and allows banks to coordinate their response to crises by forming credible mutual-insurance arrangements, which would not be possible in a system of many geographically isolated banks. These theoretical propositions receive ample support from the comparative history of banking systems and their performance (see Calomiris 1993 for a review).

In the context of universal banking, there are further advantages to becoming a large bank operating a branching network. First, if industrial firms find it advantageous to operate large-scale enterprises over a wide geographic area (as Chandler 1977 argues), then monitoring the activities of the firm will be easier if a bank has similarly wide geographic scope. Second, large branching banks are better able to take advantage of long-term relationship economies of financing firms through a universal bank because of their access to both securities purchasers and depositors. Unit banking laws that prohibit the establishment of deposit-taking branches effectively limit banks' access to deposits on a large scale and, therefore, limit large-scale lending to firms.

Furthermore, given the overhead costs of setting up a bank office, restrictions on commercial bank branching limit branching in securities retailing, too, and this raises the costs of bringing securities to market. ${ }^{10}$ Without access to a large number of securities purchasers, a bank may not be able to internalize all the benefits of collecting information about issuing firms' prospects and about the ultimate demand for firms' securities. The lack of retail branching also creates transactions and signaling costs associated with setting up networks of banks that collect and credibly transmit such information. Finally, branching reduces the physical cost of distributing securities. ${ }^{11}$ Riesser (1911, 756-57) writes that the German banks are "able to find a wider and safer market for the sale of securities which [they] proposed to float. [They] can, therefore, acquire such securities on a larger scale and with greater confidence, knowing beforehand that such securities will go into good hands as permanent investments, and not be thrown back at once upon the market, to be taken up again by the bank." Riesser also argues that large-scale banking concentrates voting power (proxies from trust accounts), which can be useful for disciplining manage-

10. Implicit in this argument are the realistic assumptions that the depositors and holders of trust accounts required a branch to be located near them, and that depositors were not indifferent to holding claims on banks in nontransactable form; otherwise, unit banking laws would not have been a binding constraint.

11. White (1985) argues that economies of scale and scope in providing investment banking and trust activities, as well as the nonbank corporate merger wave, encouraged bank mergers in the 1920s. Peach $(1941,86)$ notes that affiliates often operated large branching networks, nationally or internationally. These networks no doubt reduced transactions costs of placing issues; however, they were not substitutes for full-fledged branch banking, which involves the taking of deposits, clearing of checks, management of trust accounts, and placing of securities within the same organization. 
ment of firms banks finance. Jeidels (1905, 164-76) argues that industryspecific knowledge was important in evaluating the creditworthiness of German firms, and that economies of information gathering encouraged concentration and specialization by underwriters in particular industry niches.

Commentators on the emergence of some large-scale universal banking in the United States in the 1920s noted that one of the chief advantages of securities affiliates of commercial banks relative to investment banks was their larger size, which was due to their large branching networks. Chicago's growth as an investment-banking center in the 1920 s was encouraged by the growth of regional correspondent relations centering in Chicago, which increased the deposit and securities accounts managed by Chicago commercial banks operating investment banking affiliates (Bureau of Business Research 1928, 40).

Preston and Finlay (1930a, 1154) argue that American investors were more confident of securities underwritten by a single bank, since concentration of underwriting "centers responsibility" for the issue in one bank. They also argue that research into the creditworthiness of a firm "must involve more than simply a study of statistics: it must include continuous contact with the management of companies whose equities are selected." These large fixed costs imply that stock offerings and underwriters' resources must be large.

Despite the advantages of concentration for universal banks, regulations limiting branch banking made large-scale universal banking impossible. Long before the 1914 Clayton Act restrictions on bank involvement on corporate boards or the 1933 Glass-Steagall restrictions on universal banking activities, branching restrictions hampered the development of long-term relationships between firms and banks and made large-scale underwritings by commercial banks very rare. In the United States, after Jay Cooke's bond campaign to finance the Union during the Civil War, underwriting syndicates relied on a complex hierarchy of banks and brokers to coordinate securities transactions. This network became an important vehicle for funding underwriting, defining securities holders' demand schedules (to set prices and determine types of securities underwritten), and distributing securities once they were underwritten (Carosso 1970). The network of interbank relationships established for this purpose was an important financial innovation of the post-Civil War era. Nevertheless, in the absence of regulations prohibiting branching and consolidation across states, such coordination of information could have been accomplished (as in Germany) within syndicates of a few nationwide banks, with far fewer transactions, and with stronger incentives to collect accurate information about firms' prospects and securities holders' demands. This system also would have enhanced control over the management of public firms by concentrating voting rights in the hands of a few agents.

\subsubsection{Diversification and Universal Banking}

My discussion of universal banking has focused on corporate-finance cost reductions that come from information and transactions cost savings under a 
universal banking system. Much of the current discussion of the economies of allowing universal banking has focused on a different issue. Empirical studies of the United States in the post-World War II era have examined primarily the potential benefits of diversification that would come from combining the activities of commercial and investment banks, as well as other intermediaries. Diversification lessens the chance of costly liquidation of intermediaries and reduces transactions costs of constructing diversified portfolios for wealth holders. Some of these studies examine the relative performance of firms with diverse activities (Meinster and Johnson 1979; Boyd and Graham 1986; Litan 1985; 1987, 105-11; Wall 1987; Brewer 1989), while others consider random combinations of firms actually pursuing separate activities (Boyd and Graham 1988; Litan 1987, 112-18; Boyd, Graham, and Hewitt 1988; Brewer, Fortier, and Pavel 1988). The results from this literature have been mixed, though on balance they indicate small benefits of diversification. Not only do these studies focus too narrowly on the issue of portfolio structure, but by design they are ill-suited to measure the portfolio-diversification advantages of universal banking.

The studies of random, counterfactual combinations of different activities suffer from the obvious problem that combining firms is not the same as combining balance sheets. The behavior of financial firms might change as the result of combining activities; indeed, this underlies the arguments of economies of scope outlined above. But even the studies that analyze the comparative performance of actual combinations of financial activities will understate the potential diversification advantages from universal banking for two reasons. First, the observed combinations have occurred in the existing regulatory environment, in which many potentially beneficial combinations are prohibited by law. Second, universal banking might enlarge the feasible set of traded assets in the economy in ways that cannot be observed under the current regulatory regime.

Obviously, a better measure of the diversification benefits from universal banking would examine diversification opportunities across regulatory regimes, and within regimes that permitted universal banking. In the latter category, White's (1986) findings for the United States in the 1920s are of interest. National banks with securities affiliates had lower risk of failure than other banks. This may reflect greater portfolio opportunities for banks that could establish credible long-term relationships with borrowers. White also found that securities affiliates reduced the overall risk to bank stockholders, since the incomes from affiliates and parent banks were uncorrelated.

In a series of interesting studies, Tilly $(1980,1984,1986,1992)$ analyzes the risk-return characteristics of the portfolios created by Germany's universal banks in the pre-World War I era, and compares them with a constructed "efficient" portfolio (the efficient frontier of risk-return tradeoffs available). He finds German universal banks' portfolios remarkably close to the efficient frontier of the economy, and interprets this as evidence against the suggestions 
of some (e.g., Neuburger and Stokes 1974; Gerschenkron 1962, 15) that German banks may have preferred some industries over others for reasons unrelated to efficient capital allocation.

Cross-regime comparisons for this period are also possible. Tilly (1984, 1986, 1992) and Kennedy and Britton (1985) compare British (nonuniversal) and German bank portfolios for the pre-World War I period. They argue that British portfolios were much more distant from the efficient frontier of the British economy and far inferior to Germany in the risk-return tradeoffs they achieved.

The results of the studies of Germany and Britain are controversial, since they rely on rather heroic assumptions to measure both the efficient portfolio frontier and the portfolio created by the banks. But they draw attention to the importance of a universal banking system's ability to produce, not merely to combine, investment opportunities. As Tilly (1986, 117; 1992) emphasizes, and as is too often ignored in the empirical studies of diversification from combining banking activities in the United States today, the banking system's achievement of an efficient portfolio in Germany did not merely reflect wise choices by passive money managers of the portfolio weights to attach to a set of exogenously given investment opportunities. The German banking system, with its ability to economize on a variety of costs, was essential to making investment opportunities available to the market, and hence to expanding the feasible portfolio frontier. Opportunities for efficient construction of portfolios through universal banking depended on the ability of the banks to mitigate information, control, and transaction costs (Tilly 1992, 110).

\subsubsection{Criticisms of Universal Banking}

Perspectives on universal banking have not always been favorable. Historically, in the United States, there has been substantial opposition to allowing both the concentration of banking and the combination of commercial lending, underwriting, and equity holding by financial intermediaries. Indeed, as will be discussed in section 8.3 , for most of the period prior to the legal separation of commercial and investment banking in 1933, which forced the closing of state-chartered underwriting affiliates of commercial banks, lending and underwriting were performed mainly by different intermediaries. In particular, because banks typically were not allowed to branch or merge, they could not take advantage of the economies from internalizing the functions of the securities marketing network within a single intermediary. Changes in bank branching and consolidation permitted in the 1920s were an important precondition for the encroachments made by commercial banks into investment banking in the 1920s.

Thus, the time-honored tradition of American restrictions on the scale of banking effectively limited universal banking prior to Glass-Steagall in 1933. The outright prohibitions on investment banking affiliates of commercial banks in Glass-Steagall were justified by two accusations. First, banks were 
accused of taking advantage of conflicts of interest in securities dealings. Second, it was claimed that links between affiliates and parent banks contributed to the banking collapse of the Great Depression.

Scholars who have investigated these claims have found no supporting empirical evidence, and have disputed them on theoretical and empirical grounds (Carosso 1970; White 1986; Benston 1989; Kaufman and Mote 1989, 1990; Kroszner and Rajan 1994). On the question of whether affiliates weakened banks, White (1986) found that national banks with securities affiliates had lower failure propensities, and he linked these to diversification advantages. White also pointed out that, as documented in Peach 1941, affiliates were wholly owned by banks, and thus strategies to strengthen affiliates at the expense of parent banks would not have been chosen knowingly by management.

Benston (1989) argues that the presumed link between bank failures and securities activities of affiliates, on which much of the reasoning of the various banking committees relied, never received careful scrutiny in any of the many congressional "studies" of banking from 1931 to 1940. Nevertheless, this presumption underlay the drastic changes of the separation of investment and commercial banking in the Banking Act of 1933.

Conflicts of interest are unlikely to occur. In equilibrium, investment bankers-whether operating out of private investment banking houses or national bank affiliates-will not be able to attract customers if they cannot credibly signal the quality of securities they underwrite. If bank affiliates could not overcome potential investors' concerns over conflicts of interest (for example, by purchasing or managing some of the new issues, then they would lose business to private investment banks. The fact that affiliates were able to provide underwriting services on a large scale for many years in open competition with other underwriters indicates that conflicts of interest were not significant. Evidence against conflict of interest is provided by Kroszner and Rajan (1994). They analyze default costs for bonds issued by affiliates and their competitors prior to Glass-Steagall and conclude that the performance of affiliateunderwritten securities of a given ex ante class was at least as good as that of securities underwritten by their competitors.

Two other common criticisms of universal banking are that it increases inefficient bank rent extraction from firms, and encourages the development of industrial cartels. Coordination, of course, is not always efficient. In a concentrated banking system where firms have exclusive relationships with intermediaries, would collusion among banks in setting fees and interest rates increase the cost of finance in the economy? And would close corporate monitoring and control, along with long-term relationships between firms and universal banks, encourage the development of industrial cartels by providing a credible enforcement mechanism for collusive behavior within industries?

On the first point, it is doubtful that universal banking raises financing costs by allowing banks to extract greater rent from firms. As Rajan (1992a) shows, a banking relationship that involves the production of private information 
about firms may give banks access only to quasi rents (which are transferred back to the firm ex ante). The interesting question is whether universal banking will increase or decrease the distortions that come from asymmetric information. Here the point to emphasize is not the extent of quasi or true rents, but the way they are extracted. As argued above, universal banking may be beneficial for solving the time-inconsistency problem because it allows banks to reap long-term gains from large initial costs of investing in information. Thus, for example, banks will be able to "charge" for underwriting services partly by relying on long-term gains from their relationship with firms. In the absence of universal banking, banks may have to recover costs over a shorter horizon. This will require "front-loading" of financing costs, which will distort the firm's investment decision by making finance excessively costly in the near term. Thus, if universal banking allows banks to design compensation schemes that eliminate such distortions, then even if it increases the share of firms' rents that accrue to banks (as opposed to firms' entrepreneurs), this rent extraction may be relatively efficient. Empirical evidence (De Long 1991; Ramirez 1992) discussed below suggests that banking relationships added value to firms, and that investment bankers' fees reflected costs of providing information and transaction services, rather than simply rents. ${ }^{12}$

On the question whether investment banks promoted inefficient industrial cartels, two points are worth emphasizing. First, the development and enforcement of industrial cartels by intermediaries is not a weakness peculiar to concentrated universal banking systems. Indeed, such accusations were the hallmark of the Pujo committee hearings of 1912-13 in the United States (Carosso 1970, chap. 6). According to his critics, J. P. Morgan managed to exert as much control over "other people's money" in the context of the fragmented American banking system as would a universal bank in a concentrated banking industry. According to Louis Brandeis and Samuel Untermyer, Morgan oversaw a complex "money trust" involving corporate boards of directors dominated by investment bankers who effectively enforced collusion among firms, limited competition by commercial banks (which were controlled by the investment bankers as well), and extracted rents for investment banking firms. From this jaundiced perspective, bankers' corporate-control services were really just selling protection, Mafia-style (Brandeis 1914). With respect to the German experience, Riesser (1911) argues that bank involvement in firms was neither a necessary nor a sufficient condition for enforcing cartels. Riesser claims that the influence of the banks was "decisive in some cases, less so in others, and

12. A separate question is whether the universal bank's possibly higher share of its client firms' rents will discourage entrepreneurial investment. Universal bankers should vary the amount of rent, and the variables on which it depends, to ensure that the entrepreneur receives his reservation level of rent, and that the entrepreneur's incentives will be minimally distorted by rent extraction. In other words, a perfectly discriminating monopolistic banker with access to a "lump-sum tax" will not discourage entrepreneurial investment. Indeed, if universal banks are better able to gauge the total rents of the firm because of better information, then they will make fewer mistakes than other intermediaries in determining how much rent to extract from entrepreneurs. 
hardly perceptible in some cases" (712). Notably, in the chemical industry, industrial cartels were enforced with great apparent success despite the absence of bank involvement (721-25). Jeidels (1905, 199-252) provides a much more detailed accounting of the role of German banks in industrial cartels. $\mathrm{He}$ argues that banks focused on individual customers and were not instigators in organizing cartels. Only after firms moved to establish cartels did banks assist in enforcing arrangements so made. Both German and American history shows that bank discipline was not a unique means of enforcing industrial cartels. Policies other than prohibitions on universal banking are likely to be superior for facilitating competition within industries.

Second, it is not clear that an important or primary function of German universal banks or the American "money trust" was the enforcement of inefficient industrial cartels. ${ }^{13}$ There have been many recent challenges to the notion that the Morgan syndicate was exclusively or mainly a device for extracting rent. Carosso (1970) and Huertas and Cleveland (1987) dispute the "findings" of the Pujo committee, arguing that investment banking was a competitive, contestable business. Entry was not blocked, and firms in need of finance did not feel compelled to use the same investment banker repeatedly. There was active competition for business, and repeated contacts reflected economies of information. If these authors are right, it follows that attempts by banks to restrict competition within industries would have encouraged entry by intermediaries to finance competing industrial firms. With respect to Germany, even Alexander Gerschenkron, a staunch advocate of the notion that banks enforced industrial cartels during the period of early industrialization, argued that this was not possible after 1900 because of ease of entry into banking $(1962,15,21$, $88-89,139)$. Jeidels $(1905,122-30)$, Whale $(1930,35)$, and Tilly $(1992,109)$ support this view, arguing that German banking was a competitive industry after 1890, particularly in financing large, mature industrial firms.

Quantitative studies have been helpful, but not conclusive, in resolving the question of whether industrial cartel enforcement was historically an important

13. To the extent cartels were inefficient in Germany, it was through monopolistic restriction of output. Another possible inefficiency associated with cartels-lack of innovation-does not seem to have been relevant in Germany. Indeed, Webb (1980) argues to the contrary that cartelization of the steel industry encouraged innovation. Furthermore, the ability to solve information problems efficiently is especially important to spurring innovation, as Schumpeter (1939), Butters and Linther (1945), and many others have recognized. Here, too, German industry was at a distinct advantage, as the discussion in section 8.3 will show. Tilly (1982) also points out that acquisitions within industries by best-practice producers were frequent, and this too can be credited to financing elasticity. Financing new ideas quickly may have increased competition within industries and quickly driven out inefficient firms. One should exercise caution in interpreting comparisons of the rate of start-up of new firms in the United States and Germany as a measure of innovativeness (and costs of cartels). New firms may have been more necessary to innovation in the United States because of a lack of corporate discipline, exercised in part through intermediaries (Berle and Means 1932). As the record of post-World War II Japan shows, innovativeness can be a feature of relatively concentrated industries, particularly if the management of firms in those industries are "disciplined" (Japan Development Bank 1994). 
function of intermediaries. De Long (1991) finds that the presence of a Morgan partner on a firm's board of directors increased the value of the firm's common stock by 30 percent. More importantly, he traces this increase in stock value to the superior earnings performance of Morgan companies: "The Morgan partnership and its peers saw themselves - and other participants saw them-as filling a crucial 'monitoring' and 'signaling' intermediary role between firms and investors in a world where information about firms' underlying values and the quality of their managers was scarce. . . The presence of Morgan's men meant that when a firm got into trouble - whether because of 'excessive competition' or management mistakes - action would be taken to restore profitability" (1991, 209). De Long shows that investment banking firms were not simply vehicles for extracting rent, but he is not able to distinguish whether investment bankers increased the productivity of firms, or simply helped firms by eliminating their competition. "[T]he relative roles of monopoly and efficiency in the 'Morganization premium' cannot be determined in a fashion convincing enough to overcome prior beliefs" (224-25). Another recent study, by Ramirez (1992), connects Morgan involvement with increases in the elasticity of credit supply for firms. Ramirez finds similar advantages in reducing cashflow sensitivity of investment for German firms with universal banking connections. While these studies show that at least some of Morgan's contribution, and those of German universal banks, involved a credit relationship with the firm, they do not refute the notion that banks helped their clients by limiting competition within industry. Indeed, by giving client firms "deep pockets," Morgan may have helped them effectively threaten competitors with potential price wars.

In sum, the role of intermediaries in developing and enforcing industrial cartels remains a murky area in economic history. But to the extent such accusations have been made, they apply more broadly to the problems of all forms of interbank coalitions (notably to the American "money trust") and are not a peculiar feature of a concentrated universal banking system. Clearly, eliminating industrial cartels requires more draconian measures than restrictions on universal banking. These would include limits on cooperation, communication, and oversight among firms, banks, and securities dealers. Some of these were adopted in the United States as early as the $1890 \mathrm{~s}$, culminating in the 1914 Clayton Act prohibitions on interlocking directorates, the 1933 separation of commercial and investment banking, and the new trend toward fragmentation of both investment banking and commercial banking under the restrictive regulations of the New Deal. To the extent that these changes undermined monitoring and control networks, such drastic action may have caused more problems than it solved, by increasing financing costs of firms and by allowing firms' managers to escape the discipline of their stockholders and the marketplace (Berle and Means 1932; De Long 1991; Calomiris and Hubbard 1994). The most important point for the purposes of the German- 
American comparison in section 8.3 is that allowing a concentrated universal banking in the United States during the pre-World War I era would have had little marginal effect on industrial cartelization.

\subsubsection{Summary}

This review of general perspectives on universal banking has argued that there are significant advantages of allowing banks to combine lending, equity holding, underwriting, trust activities, and deposit taking in the same intermediary, and thus significant costs to restricting this combination of activities. The advantages of universal banking arise from a combination of three factors. First, the corporate financial life cycle (or pecking order) entails a progression in which a firm's external financing evolves from short-term debt directly held by banks to widely held equity finance underwritten by banks. The optimal form of corporate finance and governance changes as firms become seasoned. Initially, banks discipline firms and limit their exposure to risk by holding short-term senior debt. As firms become seasoned, they come to rely on junior claims for their financing needs, and intermediaries underwriting firms' stock issues protect their interests by exercising direct control over firms through boards of directors. Second, there are economies of establishing long-term relationships between firms and intermediaries that revolve around the reusability of information and the smoothing of costs of external finance over the firm's life cycle (which may only be possible within the context of a long-term relationship).

Together, firms' changing financial needs over the life cycle and the advantages of long-term relationships between firms and intermediaries imply benefits to allowing intermediaries to engage in both underwriting and lending. A universal bank's ability to provide funds to firms at low cost requires a third factor - that the bank be allowed to operate a network of branches for collecting deposits and placing and managing securities. Widespread branching allows banks to diversify when making large loans to customers. It also economizes on information and transactions costs of placing and managing securities. The costs of credibly communicating the condition of firms to outsiders, and of gauging the market demand for new securities issues, are particularly large for equity issues. Large-scale universal banking reduces these costs by placing a single intermediary between ultimate holders and securities issuers. True universal banking allows banks to combine underwriting, lending, trust activities, and deposit taking within a single branching intermediary. Thus, despite the fact that national banks operated investment banking and trust affiliates in the $1920 \mathrm{~s}$, true universal banking never was permitted in the United States because of limitations on branching that effectively limited a bank's direct access to funds, and hence its ability to finance large-scale industry.

The next section is devoted to measuring German-American differences in financial structure and costs and relating them to theoretical perspectives on 
the advantages of universal banking. I argue that the absence of universal banking in the United States, and its presence in Germany, resulted in different methods and higher costs of financing American industrialization in the preWorld War I period.

\subsection{Banking and Finance in Germany and America, 1870-1914}

By the outbreak of World War I, Germany and the United States had developed financial systems that bore little resemblance to one another. The role of banks in corporate finance and corporate control, the types of financial instruments that dominated the scene, the way financial instruments were underwritten and sold, the combinations of activities that banks performed, and the financial structure of industrial firms and banks differed sharply between the two countries. This section reviews these differences in detail along dimensions suggested in section 8.2 , focusing on consequences for the cost of industrial finance. The evidence suggests substantially higher costs of industrial finance in the United States.

In light of these differences, I describe and attempt to explain the "inversion" that took place from 1850 to World War I in German and American financial institutions. American financial institutions circa 1850, like their German counterparts circa 1900, played a much greater role in industrial finance, especially in New England's early industrialization. In antebellum New England, a financial system flourished that bore much resemblance to the mature German system. The German financial system circa 1850 was more fragmented and less integrated than New England's, but rapidly progressed after 1870 , and quickly developed a concentrated universal banking system. At the same time, New England's financial system moved away from its early structure, and from financing industrial activities of those closely involved with the banks. The "regressive" history of American banking from 1850 to 1920 reflected the increasing scale of industrial borrowers and their credit needs and the restrictions on bank branching and consolidation, which kept banks' size and geographical scope small while the size and scope of their customers grew. These restrictions on U.S. banks prevented them from reaping advantages of universal banking long before the separation of commercial and investment banking in 1933 .

\subsubsection{Relative Factor Intensity and Capital Scarcity in \\ U.S. and German Industrialization}

The second industrial revolution, beginning in the mid-nineteenth century, saw rapid industrial expansion especially in the areas of railroads, steel, chemicals, and electricity. Germany and the United States were among the most impressive examples of industrial growth during this period, although Germany's heyday of industrial expansion began later than that of the United States. As table 8.1 shows, in the United States, nonagricultural output grew most rapidly 


\begin{tabular}{|c|c|c|c|c|c|}
\hline & \multicolumn{2}{|c|}{ Germany } & \multicolumn{3}{|c|}{ United States } \\
\hline & $\begin{array}{c}\text { Nonagricultural NNP } \\
1913 \text { Prices } \\
\text { (millions of marks) }\end{array}$ & $\begin{array}{l}\text { Nonagricuitural Labor } \\
\text { (thousands) }\end{array}$ & $\begin{array}{c}\text { Nonagricultural VA } \\
1879 \text { Prices } \\
\text { (millions of } \$ \text { ) }\end{array}$ & $\begin{array}{c}\text { Nonagricultural NI } \\
1869 \text { Prices } \\
\text { (millions of \$) }\end{array}$ & $\begin{array}{c}\text { Nonagricultural Labor } \\
\text { (thousands) }\end{array}$ \\
\hline 1849 & & & 670 & & \\
\hline 1850 & 5,052 & & & & \\
\hline 1869 & & & 1,550 & 5,325 & 6,193 \\
\hline 1870 & 8,431 & & & & \\
\hline 1871 & & 8,796 & & & \\
\hline 1889 & & & & 7,543 & 12,540 \\
\hline 1890 & 15,857 & 12,807 & & & \\
\hline $1910-13$ & & & & 16,519 & 20,871 \\
\hline 1913 & 37,210 & 20,267 & & & \\
\hline
\end{tabular}

Sources: Real nonagricultural activity in the United States was calculated using value added in mining, manufacturing, and construction for 1849-69, from Gallman, as reported in U.S. Department of Commerce 1975, 239. For 1869-1913, I used Martin's data on current national income outside of agriculture (U.S. Department of Commerce 1975, 240), deflated by a nonagricultural output deflator. This deflator was consructed as follows. Romer's (1989,22) GNP deflator is assumed to equal a weighted average of the nonagricultural deflator and the agricultural deflator (from Warren and Pearson for 1869-1890 and BLS for 1890 to 1910-13, as reported in U.S. Department of Commerce 1975, 200-201, using Martin's weights for agricultural and nonagricultural income. For Germany, nonagricultural net national product and labor are derived from Hoffmann $1965,205,454-55$.

Notes; $\mathrm{NNP}=$ net national product; $\mathrm{VA}=$ value added; $\mathrm{NI}=$ national income . 
from 1850 to 1870 , while in Germany rapid growth was more concentrated in the period from 1870 to the First World War. In the United States, value added in manufacturing, mining, and construction more than doubled from 1849 to 1869. Nonagricultural income grew by less than half from 1869 to 1889 and doubled from 1890 to 1913. In Germany, nonagricultural net product increased by less than half from 1850 to 1870 , then doubled from 1870 to 1890 and more than doubled from 1890 to 1913 .

Despite the similarity in nonagricultural output growth rates in Germany and the United States from 1870 to 1913 , the way growth was achieved was quite different. In the United States, employment in the nonagricultural sector grew by the same rate as output, while in Germany nonagricultural employment grew at half the rate of output. Relative to Germany, American industrialization relied more intensively on labor.

Goldsmith (1985) defines three capital-to-output ratios, using broad, intermediate, and narrow definitions of capital. The intermediate measure excludes land, and the narrow measure also excludes consumer durables and residential structures. A comparison for all three measures, for Germany and the United States at selected dates from 1850 to 1913, is provided in table 8.2. The German capital-to-output ratio is substantially higher than that of the United States regardless of which measure is chosen, but the proportionate difference between the United States and Germany is greatest for the narrow measure, which focuses on the reproducible capital of producers. On average, from 1850 to 1913 , the U.S. narrow capital-to-output ratio is half that of Germany. ${ }^{14}$

Field (1983, 1987) and Wright (1990) have emphasized the reliance placed by the United States on substitutes for fixed capital in the production process, especially natural resources. As Cain and Paterson (1981) document, materials prices fell sharply in the United States after the Civil War. Continuing discoveries of new resources, especially metals and oil fields, kept resource costs low throughout the pre-World War I period. Wright $(1990,658)$ notes that U.S. exports had far higher resource content than imports and that the resource intensity of exports increased substantially during late-nineteenth-century industrialization. By 1928, resource intensity of exports was 50 percent higher than its 1879 level. Wright follows Piore and Sabel (1984) and Williamson (1980) in linking the American utilization of resources with the "high-throughput" system of manufacture emphasized by Chandler (1977), which Field (1987) points out is a means to economize on capital costs. Wright and others also emphasize that the reliance on resources in the United States was not exogenously determined. America's natural resource base is not among the richest in the world. Rather, the American reliance on natural resources, the develop-

14. The capital intensity of the German economy in 1850 cannot be attributed to universal banking, since universal banking under limited liability laws began in 1870 . Centralized government subsidization and planning of railroads, built ahead of demand, may account for the large capital-to-output ratio in the pre-1870 period (Dunlavy forthcoming). 
Table 8.2

Ratios of Capital to GNP

\begin{tabular}{|c|c|c|c|c|c|c|}
\hline & Narrow Capit & Measure & \multicolumn{2}{|c|}{$\begin{array}{c}\text { Intermediate Capital } \\
\text { Measure }\end{array}$} & \multicolumn{2}{|c|}{ Broad Capital Measure } \\
\hline & United States & Germany & United States & Germany & United States & Germany \\
\hline 1850 & 1.24 & 4.20 & 1.66 & 5.04 & 2.83 & 9.29 \\
\hline 1875 & & 3.29 & & 4.26 & & 7.12 \\
\hline 1880 & 1.78 & & 2.45 & & 3.56 & \\
\hline 1895 & & 2.70 & & 3.79 & & 5.68 \\
\hline 1900 & 1.81 & & 2.91 & & 4.56 & \\
\hline 1912 & 1.71 & & 2.69 & & 4.17 & \\
\hline 1913 & & 3.42 & & 4.82 & & 6.58 \\
\hline
\end{tabular}

Source: Goldsmith 1985, 39-42.

Notes: Narrow capital is nonresidential structures, equipment, inventories, and livestock. Intermediate capital is narrow measure plus residential structures and consumer durables. Broad capital is intermediate measure plus land.

Table 8.3

Components of Tangible Reproducible Assets

\begin{tabular}{lcc}
\hline & $\begin{array}{c}\text { Germany (1913) } \\
(\%)\end{array}$ & $\begin{array}{c}\text { United States (1912) } \\
(\%)\end{array}$ \\
\hline Dwellings & 25 & 24 \\
Other structures & 31 & 35 \\
Equipment & 26 & 13 \\
Inventories & 10 & 10 \\
Livestock & 5 & 5 \\
Consumer durables & 3 & 13 \\
\hline
\end{tabular}

Source: Goldsmith 1985, 111.

ment of production techniques that were resource intensive, and the emergence of high-throughput production and distribution processes were induced in part by the high cost of raising capital.

Goldsmith's (1985) breakdown of the components of the capital stock also provides interesting evidence about differences between the United States and Germany in the allocation of capital across different uses. Table 8.3 compares the shares of various components of tangible reproducible assets for Germany in 1913 and the United States in 1912. The shares of livestock, inventories, and structures are quite similar. The principal difference is the relative importance of equipment and consumer durables. In Germany, equipment is 26 percent of reproducible assets, while in the United States, it is half that percentage. Conversely, in the United States, consumer durables account for 13 percent of the total, while in Germany they make up only 3 percent. Comparisons for other years during the interval 1850 to 1900 lead to similar results, although in 
Germany the relative importance of equipment in reproducible assets grew during the pre-World War I era.

While there are many possible interpretations of the different weights for equipment in Germany and the United States, two points warrant emphasis. First, the greater relative weight in Germany is unlikely to be the result of measurement error. Both countries' data are derived from the same individual's work-Goldsmith 1955-56, 1976; and Goldsmith, Lipsey, and Mendelson 1963. Thus, gross incomparabilities across categories or insensitivity to data source differences are unlikely to explain the differences. One problem worth worrying about is whether the German data on equipment include items that would have been excluded from consumer durables in Germany, but included in consumer durables in the United States. I examined the items included in U.S. consumer durables to see whether production equipment located at home might explain the observed differences. Goldsmith (1955-56, 1:680) reports nonfarm individuals' expenditures on the main categories of consumer durable goods. These categories include "furniture, household appliances, house furnishings, china etc., musical instruments, books, passenger cars, passenger car accessories, medical appliances, and miscellaneous." None of these sounds like production equipment. Even if "household appliances" or "miscellaneous" includes some producer durables, these constitute such a small share of total consumer durables (16 percent in 1913) that they could not account for the difference between German and American equipment shares.

The second point to emphasize, in anticipation of the discussion that follows, is that the greater reliance on equipment in Germany is consistent with a lower cost of financing industrial expansion, particularly in the form of largescale factory production. ${ }^{15}$ Equipment-intensive production is more capital intensive because of its lower "throughput" rate (Field 1987). Also, equipment is less liquid than materials, which makes it harder to collateralize and finance.

\subsubsection{Interregional and Intersectoral Capital Allocation in the United States}

The cost of capital was not uniform within the United States across locations, sectors, or time. Interregional and intersectoral differences in rates of return on capital in the United States (a measure of inefficiency in capital allocation) were largest during the mid- to late nineteenth century. But even as late as the $1920 \mathrm{~s}$, Federal Reserve surveys show that interest rates on like bank loans in provincial U.S. cities could be 4 or 5 percent higher than rates in eastern financial centers (Riefler 1930,79). Breckenridge $(1899,5)$ contrasted the enormous interregional variation in low-risk U.S. interest rates with those of European countries, including Germany. For Germany, he cites evidence that the interest rates in 260 provincial towns were identical to those charged

15. It is also interesting to note that the production of producer durables is relatively capital intensive. Creamer and Borenstein $(1960,52)$ show that the capital-output ratios of capitalequipment industries were 1.05 in 1900 , compared to 0.68 for consumption-goods industries. 
in Berlin for loans of a standard quality. As Bodenhorn (1992) shows, the antebellum United States did not suffer from large interregional differences in costs of funds. The integration of capital markets seems to have worsened during the geographical expansion and industrialization of the postbellum era. In their study of the profitability of American enterprises from 1850 to 1880 , Atack and Bateman (1992) find that interregional profit-rate differentials in the United States were largest in the industrial sector, that industrial profit rates were far above profit rates in other sectors, and that convergence in profit rates for manufacturing was most protracted. They attribute this to capital immobility across regions and across sectors that kept the capital stock of manufacturing enterprises low.

\subsubsection{The Different Roles of Banks in Industrial Finance}

Qualitative discussions of the importance of German banks to industrial progress date from Jeidels 1905, Riesser 1911, Schumpeter 1939, and Gerschenkron 1962. Goldsmith (1985) provides detailed comparative analyses of many countries, and quantitative measures of important features of German finance from an international comparative perspective. Goldsmith (1958) and Goldsmith, Lipsey, and Mendelson (1963) analyze the funding sources of American industrialization in detail.

Goldsmith $(1985,135)$ defines the "financial intermediation ratio" as a rough, general measure of the economy's reliance on intermediation for the creation of wealth. The financial intermediation ratio for Germany rose from 20.3 in 1850 to 30.1 in 1913 . Over this same period, the U.S. ratio rose from 12.5 to 21.3. By this measure, the United States was fifth from the lowest in a field of thirteen, while Germany was near the top. Seven nations had ratios in excess of 29 for 1913, and the average ratio for twelve nations (excluding the outlier, India, with a ratio of 8 ) was 27.

If one focuses on the specific links between bank lending and industrialization, the contrast between the roles of banks in Germany and the United States is greater. In Germany, the universal banks were responsible for providing a large share of industrial finance. The financing of industrial credit involved some four hundred joint-stock banks operating more than one thousand branches nationwide by 1913. Eleven large incorporated banks accounted for more than one-third of the capital and assets of the system. Banks lent directly to firms through very short-term overdraft accounts (with average maturities of less than one month), held and managed stocks and bonds of firms, and acted as investment bankers for firms' securities issues. The importance of universal banking in German industrial finance was especially pronounced after the 1890' consolidation movement in banking, which Jeidels $(1905,83-107)$ argues largely reflected the increasingly large-scale financing needs of industry.

Consistent with section 8.2 's discussion of the changing role of universal banks over the life cycle of the firm, new projects were often financed directly through short-term bank loans. Later, financing was transformed to long-term 
securities, placed by the bank that had originally made the loan (Jeidels 1905 , 109-22; Riesser 1911, 364-69; Whale 1930, 37-38; Eistert 1970, 91). Jeidels (1905) provides a detailed accounting of the involvement of banks over the life cycle of firms. The first stage of the firm-bank relationship saw keen competition among banks in the loan market for overdraft credit accounts (Jeidels 1905,122 ). Interest costs for overdraft credit were typically set at the interbank lending rate plus 1 percent (Whale 1930,37-38). In the early stages of the firm life cycle, the bank's main lever of influence over the firm was the threat of revoking the line of credit. Jeidels (126) cites as an example of bank discipline a 1901 letter the Dresdner Bank wrote to one of its customers, threatening cancellation of credit if an upcoming vote by the board of directors went the wrong way. As the firm-bank relationship matured, equity took the place of overdraft credit and the bank's role in corporate governance changed from threatening the board of directors to becoming part of the board of directors (Jeidels 1905, 128). On occasion, when bank positions were challenged by other members of boards of directors, banks resorted to massive purchases of company stock to secure controlling interest (Jeidels 1905, 111). Still later in the firm's life cycle, the influence of its principal banker typically waned, and other banks competed for its underwriting business (Jeidels 1905, 128-30).

With respect to the quantity of bank holdings of claims on firms, table 8.4 reports Eistert's year-end estimates of the amount of direct overdraft financing of industry (a component of overdrafts, or Kontokorrentkredite, from which Eistert excludes overdraft lending for securities transactions and bankers acceptances for financing trade). Table 8.4 also reports the amount of "permanent" participations of the banks (typically confined to bank shares in subsidiary financial institutions: Whale 1930, 47-48, 150), banks' other securities holdings (including underwriting inventories), and the amount of bankers acceptances financing commerce. The table also displays each of these asset categories as a fraction of total bank assets. While banks played an important role as holders of claims, just as important was their role in helping firms graduate (apparently rapidly) to find ultimate sources of funds outside the banking system. Thus, the banks used their special position as "delegated monitors" to "lever" their clients' finances - allowing their clients to reach a broad market for external finance by providing direct lending at early stages of projects, and later underwriting equity as a signal of their clients' quality possibly and as a vehicle for sharing in capital gains (as argued in section 8.2's discussion of time consistency).

Jeidels $(1905,106)$ and Eistert $(1970,142)$ interpret the rising importance of Kontokorrentkredite after 1890 as evidence of increasing bank involvement in financing new industrial projects after the $1890 \mathrm{~s}$, which they see as significant evidence of the role of banks in priming the pumps of industrial finance during this crucial period of German industrial growth. The bank acted as a monitor of the firm's conduct, a source of discipline over management (through 


\begin{tabular}{|c|c|c|c|c|c|c|c|c|}
\hline & $\begin{array}{l}\text { Industrial Credit } \\
\text { (millions of marks) }\end{array}$ & $\%$ & $\begin{array}{c}\text { Acceptances } \\
\text { (millions of marks) }\end{array}$ & $\%$ & $\begin{array}{c}\text { "Permanent" } \\
\text { Participations } \\
\text { (millions of marks) }\end{array}$ & $\%$ & $\begin{array}{l}\text { Other Securities } \\
\text { (millions of marks) }\end{array}$ & $\%$ \\
\hline 1888 & 329.1 & 12 & 448.3 & 16 & 32.4 & 1 & 338.4 & 12 \\
\hline 1893 & 416.5 & 12 & 631.5 & 18 & 67.9 & 2 & 351.9 & 10 \\
\hline 1898 & 902.1 & 14 & 984.4 & 15 & 183.4 & 3 & 728.0 & ll \\
\hline 1903 & $1,334.2$ & 15 & $1,301.2$ & 15 & 236.1 & 3 & 956.5 & ll \\
\hline 1907 & $2,336.6$ & 18 & $1,890.7$ & 15 & 439.4 & 3 & $1,289.6$ & 10 \\
\hline 1913 & $2,930.3$ & 18 & $2,450.6$ & 15 & - & - & - & - \\
\hline
\end{tabular}

Sources: Industrial credit and acceptances derived from Eistert 1970, 92. Data for permanent participations and other securities are from National Monetary Commission 1910, table 15, except for total assets for 1913. Total assets for 1913 is taken from Deutsche Bundesbank 1976, 56.

Notes: Some asset categories are omitted from this table, including cash assets, collaterlized loans, and lending for securities purchases. Industrial credit is defined as Kontokorrentkredite (overdraft account credit) for industrial purposes. Acceptances are bankers' acceptances used primarily to finance goods in transit. Permanent participations are long-term securities holdings of banks, which are mainly stock held in other (essentially subsidiary) financial institutions. Other securities pertains to all other securities held, which mainly reflects ongoing underwriting activities. 
directorates and voting of clients' shares), and a source of advice on financial and business organization.

Specific evidence from industry case studies on the role of German banks in industrial finance is abundant. Jeidels (1905) and Riesser (1911) provide lengthy discussions of the evolution of the major German industries and the roles played by banks. For example, Riesser (1911, 713-21) argues that assistance by informed bank lenders was crucial to the development of the electrical industry. He discusses the coevolution of firms and banks and describes how the role banks played changed with the industrial organization of the industry. Initially, banks promoted widespread entry by a multitude of firms, and funding of firms' needs was accomplished through direct lending, followed later by placements of securities. As the industry developed, consolidation of firms raised the scale of financing needs, which in turn, increased the need for interbank cooperation through financing syndicates. Banks reinforced the trend toward industrial concentration by helping to coordinate decision making among firms. The history of the electrical industry illustrates how banks encouraged technological innovativeness at the crucial early stage of industrial development and made efficient large-scale operations feasible. The Germans developed a larger and more interregional electrical utility system than that of Britain or the United States during this period (Hughes 1983). Carlson (1991) argues that the greater fragmentation of the U.S. electrical system reflected financing constraints. On the demand side, utility customers were financed by electrical manufacturers rather than banks. According to Carlson, this hampered the ability of manufacturers to expand and integrate their operations, and led to a less standardized range of products in the United States.

Links between industrial firms and banks were much weaker in the United States. This reflected in large part the small size of incorporated banks relative to the large needs of industrial borrowers. More than twenty-six thousand banks were operating in 1914, and the overwhelming majority of these were not permitted to operate branches, even within their home state. Even the limited operation of universal banking through securities affiliates did not begin in earnest until after World War I. The first three investment aftiliates of national banks were organized between 1908 and 1917, and served as models for the growth of affiliates in the 1920s (Peach 1941, 18-20, 61-64).

Much of bank financing of firms occurred without any direct (much less ongoing) relationship between the bank and the firms it financed. Intermediaries' claims on firms primarily took the form of corporate bond holdings placed through syndicates. According to Goldsmith $(1958,222)$, for the period 190112 , bonds held by all intermediaries accounted for 18 percent of funds supplied by external sources (that is, excluding retained earnings) to nonfinancial firms. Commercial banks accounted for two-thirds of corporate bond holdings by intermediaries in 1912. ${ }^{16}$ Based on flow-of-funds accounting, bank loans (for

16. Goldsmith $(1958,335)$ gives total intermediaries holdings of bonds. He provides data on commercial banks' bond holdings, decomposed according to type of issuer (339-40). 
all purposes) accounted for 12 percent of externally supplied funds for 190112. Using balance-sheet data of nonfinancial corporations for 1900 and 1912, Goldsmith, Lipsey, and Mendelson (1963, 2:146) calculate that bank loans amounted to roughly 10 percent of firms' debts, and less than 5 percent of firms' assets. Bonds and notes accounted for roughly half of firms' debts, and trade debt made up 15 percent. The use of short-term bank lending to finance industrial operations, as distinct from commerce, cannot be quantified (see Goldsmith 1958, 344).

Reliance on bank loans was relatively high for small firms. Large manufacturing firms relied more on bond issues as a means of indirect bank finance (Goldsmith 1958, 217-18) and less on loans from banks as a source of financing, especially prior to the 1940s. Of course, under a unit banking system, large-scale firms operating throughout the country would have had to borrow from many small unit banks simultaneously. Bond market syndications facilitated this transaction by providing a means for banks to share risk and coordinate capital allocations. The commercial paper market (a unique innovation of the American financial system) performed a similar role for short-term borrowing needs of large, high-quality borrowers. From humble beginnings in the 1870 s, the commercial paper market reached its pre-World War II peak in 1920 at $\$ 1.3$ billion, consisting of the debts of over four thousand borrowers (Selden 1963, 8).

Dobrovolsky and Bernstein $(1960,141-42)$ report funding sources for a sample of fourteen large manufacturing firms from 1900 to 1910 , based on accounting records of sources of net inflows of funds. For the period 19001910 , these firms reported a total financial inflow of $\$ 1.2$ billion, of which $\$ 357$ million came from external finance. Of this, only $\$ 29$ million was in the form of short-term debt. Some bank loans during this period also took the form of long-term debt, but judging from Goldsmith (1958, 335, 339), long-term loans from commercial banks were uncommon around the turn of the century.

While small firms relied more on banks, it does not follow that banks contributed to the financing of industrial capital expansion by small firms any more than they did to that of large firms. Two detailed studies of the sources of capital in manufacturing provide a glimpse of the contribution of banks to industrial expansion in Illinois (Marquardt 1960) and California (Trusk 1960) in the mid- to late nineteenth century. In the case of California, thirty-three of seventy-one manufacturing firms studies over the period 1859-1880 financed their investment entirely from internal sources. The others incorporated, took in partners, and supplemented these sources with earnings of existing partners from other sources, sale of stock or real estate, "eastern capital" (in three cases), and loans from a private banker (the same banker in both instances). Clearly, commercial banks had no role in the expansion of manufacturing capital in California prior to 1880 .

Illinois's experience was similar, but the role of banks in financing industrial expansion may have been greater. The rapid expansion of manufacturing in Illinois began in the 1860 s. From 1860 to 1870 , manufacturing production 
and capital each increased sevenfold, and employment increased sixfold. From 1870 to 1880 , manufacturing production doubled. Marquardt (1960) examined the personal and business histories of fifty entrepreneurs. She found that these firms were financed initially from accumulated savings of would-be manufacturing entrepreneurs, or by entrepreneurs taking on a partner with savings. Subsequent funding typically was provided by retained earnings. Occasionally, this was supplemented by the sale of entrepreneurial assets, the expansion of the partnership, or incorporation. In twenty-six out of fifty cases, manufacturing entrepreneurs of relatively mature firms used profits to invest in an interest in a bank, which "marked the beginning of more rapid success for them. They owned in part or had access to, funds, either large or small, which would enable them to grow and to progress." This was especially important in the $1860 \mathrm{~s}$ because manufacturing was moving rapidly toward mechanization and opportunities for expansion outpaced accumulated profits (507). In short, firms progressed up the pecking order as they matured. Entrepreneurs secured access to external funds by investing in banks, on which they could rely for funds. While Marquardt's study does indicate a role for banks in industrial finance, it says as much about the limits of that role as it does about banks' potential importance. Access to bank funds was extremely limited, and bank stockholders were given preference as bank borrowers. Such a system had worked well to provide the needs of business in New England in the antebellum period (Lamoreaux 1994), but by the 1870 s, this system was insufficient. Restrictions on insider lending, combined with the rising scale of manufacturing and the limited size of unit banks, meant that access to a unit bank's deposit base could not keep pace with the needs of bank insiders. Thus, while banks may have played a role in financing industrial expansion in Illinois and elsewhere, the importance of this role was limited to the "adolescent" stage of the firm's life cycle-after the firm had become mature enough to invest in becoming a bank insider, but before the firm had become too large to rely on a unit bank for its funding needs. Even this role of banks in industrial finance is apparent only in the histories of some firms (roughly half of those chosen for case studies by Marquardt).

To summarize, unlike German industrialists, American industrialists could not depend on a single banking relationship to guide them through their growing and changing financial needs over the years. They relied less on banks for credit, especially to finance large-scale projects. At each stage in their financial life cycle, firms had to change their financial relationships as they moved to new financial instruments and new funding sources for their investments. The small size of banks limited bank lending to large-scale firms. Even relatively large banks in major cities considering lending to industrial firms would have foreseen limited future relationships with borrowers, making some lending prohibitively expensive (Mayer 1988). Finally, given the reduced role of intermediaries in direct lending, bank finance of industry was limited mainly to holding securities placed through syndicates. The form of these financial instruments and their costs are subjects to which I now turn. 


\subsubsection{Financial Instruments and the Financial Structure of Industrial Firms}

Section 8.2 highlighted some important disadvantages of long-term debt financing compared to a combination of short-term debt and equity. Relative to short-term debt, long-term debt can be costly because of incentive problems (the firm's incentive to add risk increases in the absence of a rollover option). Relative to equity, all forms of debt increase the probability of financial distress by raising leverage. Finally, when a firm's debt takes the form of dispersed debt holdings, rather than concentrated lending from intermediaries, the costs of managing financial distress (coordinating workouts) is increased (see Riesser $1911,365-66$, on German banks' roles in managing reorganizations). For all these reasons, long-term debt is a costly form of finance. If, however, firms are constrained to finance themselves through syndication networks rather than through intermediaries, then the transactions costs of rollover of short-term debt can be prohibitive. And equity may not be a feasible alternative to debt, either because the costs of resolving asymmetric information between firms and ultimate sources of funds are large (because the "lemons discount" for equity will be larger than that for debt, as in Myers and Majluf 1984), or because the equity holder is unable to exert control over corporate management (Jensen and Meckling 1976). Baskin (1988) argues that asymmetric information explains the dearth of equity issues historically in the United States. Thus, despite its high costs, long-term debt may be the best means for firms to raise funds in the absence of large-scale, universal banking. Of course, in light of incentive problems of issuing long-term debt, risky firms may be denied access to this market as well, leaving them to rely on retained earnings alone as a source of finance. ${ }^{17}$

According to this interpretation of long-term debt as a "last resort" in the absence of alternatives-albeit one not available to all firms-one would expect the structure of German firms' balance sheets to rely far less on longterm debt than do American firms. Table 8.5 confirms this prediction. Private domestic corporate bond issues are a much smaller fraction of total securities issues in Germany than in the United States over the pre-World War I period, and represent a relatively small fraction of outstanding corporate claims. Moreover, the German data on bond issues are for gross issues, while the U.S. data are for net issues; thus, the difference reported in table 8.5 in the relative amount of stock and bond issues understates the true difference. In Germany,

17. Indeed, access to bond markets has sometimes been very selective. Calomiris and Hubbard (1994) found that very few firms in their sample of publicly traded firms in the mid-1930s had access to the bond market. Only a quarter of all firms issued bonds, and 10 percent of firms accounted for 90 percent of bond issues. Bond-issuing firms were three time as large as non-bondissuing firms. Interestingly, while firms with higher measured costs of finance had higher debt ratios, they were less likely to have outstanding debt in the form of bonds. These data lend support to the view that incentive problems of long-term debt may have limited its use. An alternative explanation for the Calomiris-Hubbard sample would argue that access to the bond market was substantially limited by regulatory change in 1935. Prior to the Banking Act of 1935, banks were allowed to sell low-grade bonds to their customers. After 1935, this was prohibited (Haven $1940,7)$. 
Table 8.5

\section{Corporate Finance in Germany and the United States prior to} World War I

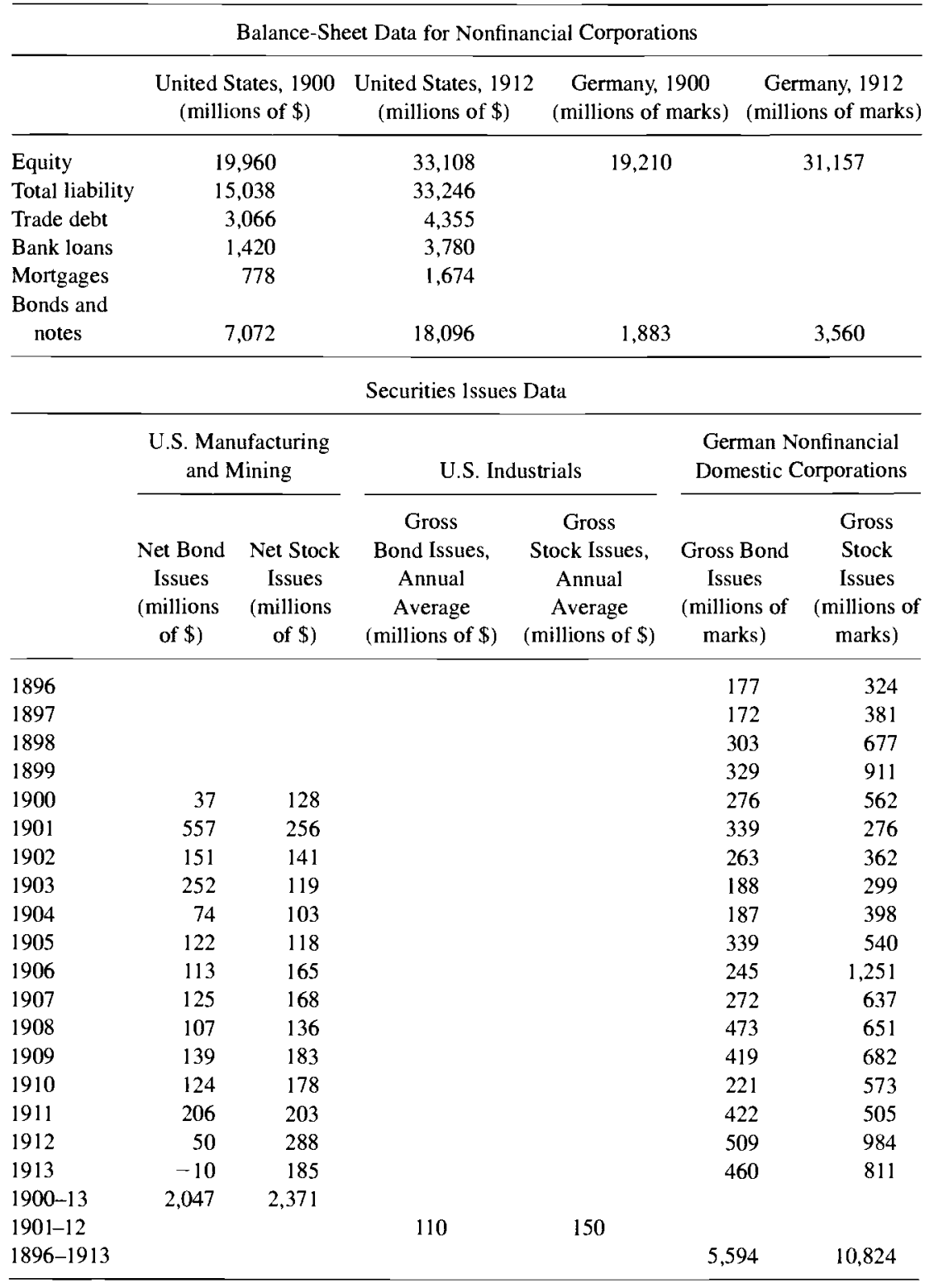

Sources: Balance sheets of U.S. nonfinancial corporations are from Goldsmith, Lipsey, and Mendelson 1963, 2:146. German data on equity and bonds are from Deutsche Bundesbank 1976, 290, 294. The German data on bonds seem to be face values (which are essentially the same as market values). 
Table 8.5

(continued)

To calculate the market value of German equity, I combined the book-value estimate (290) with the market-to-book-value index for corporate stocks (294). For example, German equity book-value in 1900 was 10,384 million marks and the index was 1.85 . Data on securities issues of U.S. manufacturing and mining corporations are from Dobrovolsky and Bernstein 1960, 333. Data on securities issues of industrials are from Friend 1967, 68. Data on German securities issues are from Eistert 1970, 105.

firms made a relatively rapid transition from Kontokorrentkredite into the equity market, and relied relatively little on bond finance. In the United States, industrial finance through outside equity was more limited. Indeed, as Carosso $(1970,81-82)$ points out, for many industrial and retail establishments prior to World War I, outside equity issues were not a possibility. As Doyle (1991) points out in his detailed analysis of sugar-refining and meat-packing industries, equity issues of American firms during this period typically were associated with "strategic" restructuring of the firm's preexisting liabilities, and not with the financing of industrial expansion.

\subsubsection{The Financial Structure of Banks}

Sources of finance for banks also were very different in Germany and the United States, with German banks relying to a much greater extent on equity rather than deposits as a source of funds. Of course, unlike national banks, the German credit banks did not issue currency, so one might expect them to show larger equity ratios than American banks for this reason. But this does not explain the difference. State-chartered banks in the United States lacked noteissuing authority, but had similar capital ratios to national banks. As table 8.6 shows, the difference between German banks' and U.S. national banks' capital-to-asset ratios is larger than can be explained by the presence of notes on national bank balance sheets.

The high German capital ratios are especially puzzling when one considers the large size of German banks compared to U.S. banks. Within the United States, larger banks tended to have lower capital ratios than small banks. For example, Calomiris (1993) shows that branching banks in California had half the capital ratios of other U.S. banks. Similarly, adjusting for differences in portfolio risk, large nationwide (nonuniversal) commercial banks in Canada had lower capital ratios than their American counterparts. Calomiris (1992) argues that lower capital ratios for large commercial banks reflected risk reductions brought about by large size. As banks became large, they were able to satisfy depositors' concerns about risk with smaller capital ratios. Banks wanted to conserve on capital because it was a relatively expensive form of finance. The limitation on banks' access to capital is illustrated by the fact that the demand for bank stock was confined mainly to investors located near the bank. A study by the Comptroller of the Currency of stock ownership in national banks in 1897 revealed that the largest out-of-state holdings were for the 


\begin{tabular}{lcc}
\hline & $\begin{array}{c}\text { German Credit Banks } \\
\text { (millions of marks) }\end{array}$ & $\begin{array}{c}\text { U.S. National Banks } \\
\text { (millions of \$) }\end{array}$ \\
\hline Net worth (book) & 2,873 & 1,341 \\
Liabilities & 6,518 & 5,364 \\
Deposit accounts & 1,897 & \\
Credit accounts & 3,301 & \\
Acceptances & 1,320 & 433 \\
Currency issued & 0 & 0.25 \\
Net worth/liabilities & 0.44 & \\
\hline
\end{tabular}

Sources: National bank balance-sheet data are derived from state-level data reported in Board of Governors of the Federal Reserve System 1959. National banknotes are from Board of Governors of the Federal Reserve System 1976, 408. German data are from National Monetary Commission 1910 , table 15 .

western and Pacific regions, which had out-of-state holdings of less than 12 percent (Breckenridge 1899, 10). Thus a possible explanation of the higher capital ratios of German universal banks could be the higher demand for bank stock by "outsiders."

What would explain higher demand by outsiders for universal banks' stock? First, given the potential for German nonfinancial firms to issue large amounts of equity, "thick-market" externalities may have favored similar financing by banks. Second, if German banks were better able to communicate information about their portfolio risks to their stockholders, then lemons discounts would be mitigated, allowing them to reap the advantages of equity finance. Thus, the efficiency of capital markets in Germany due to universal banking may have helped finance banks, too. Third, the confidence of outsiders in bank stock may have been enhanced by a reputational effect. If outsiders were aware that banks had long-term reputational capital worth preserving, then they should have been less concerned about short-term cheating by banks. Thus, the disciplinary role of demandable debt (stressed by Calomiris and Kahn 1991, and Calomiris, Kahn, and Krasa 1992) would be less relevant for German banks. From this perspective, German banks may have been able to finance themselves more through outside equity than American banks because of long-run benefits they could expect to realize through their relationships with firms. These long-run benefits increased the reputational consequences of cheating and helped to support the credibility of bankers.

It may never be possible to distinguish among these explanations for the higher equity ratios of German banks. But this decomposition is relatively unimportant. The important common feature of all these explanations is their dependence on universal banking as a precondition to permitting banks to rely on outside equity as an important source of finance. 


\subsubsection{Investment Banking Spread as a Measure of Financing Efficiency}

An important dimension of cost savings stressed in section 8.2's discussion of the benefits of universal banking is the reduction in the cost to firms of underwriting and distributing securities. The investment banker's "spread" is defined as the difference between the market value of securities issued and the value received for these issues by the issuing firm. Data on spreads are useful for three purposes. First, average issue costs provide an overall comparison of the costs of issuing securities in the United States and Germany. Second, variation in spreads across securities and firms of different types can be used to gauge cross-country differences in the relative costs of issuing particular kinds of securities. For example, one would expect equity issues to be especially costly in the United States relative to Germany because of the greater costs of placing junior securities in a nonuniversal banking system. Finally, firm-level data on the factors that raise or lower costs of securities issues offer evidence on the sources of the costs of issuing bonds and stocks. For example, one can examine whether bankers' spreads primarily reflect information costs, physical transactions costs, taxes, or economic rents of the investment banker.

American investment bankers have guarded the details of their financial arrangements carefully, and data on investment bankers' spreads are notoriously hard to come by. For the United States, detailed data are known only for a few cases prior to the 1920s, and only after 1936 are data available for the whole population of securities issuers. For Germany, I have been able to locate some data on individual spreads for the pre-World War I period from Saling's Borsen Jahrbuch (the German equivalent of Moody's Industrial Manual). For many firms (roughly half), Saling's reports details of the underwriting costs of equity issues and/or the total amount of funds received by firms through equity issues. A minor problem with the data is that it is not always clear whether reported numbers include fees other than bankers' commissions. Equity issues entailed local and national taxes, as well as physical costs (printing, etc.). From examples where the breakdown of such costs are known, the total costs of taxes and physical expenses seem in the range of 2-3 percent. For example, Harpener Bergbau A. G., a large Dortmund mining company, issued 9 million marks of stock in 1909 . The spread was 436,000 marks, or 4.84 percent of the issue. Of this cost, 176,000 marks (40 percent of the total cost) reflected the national government tax on equity issues. ${ }^{18}$ Thus, in the absence of the government's securities tax, the bankers' spread would have been 2.9 percent. While reported data on commissions may overstate true commissions (because bankers sometimes paid these fees for firms), and reported data on total costs may understate total costs (because measured costs may not always include federal or local taxes), errors from these sources cannot be large, and data from firms that reported both measures indicate that reported total costs generally in-

18. I thank Richard Tilly for providing this example. 
Table 8.7

Bankers' Commissions (Spreads) and Total Issuing Costs for German

Common Stock Issues, 1893-1913 (\%)

\begin{tabular}{|c|c|c|c|c|c|c|}
\hline & $\begin{array}{c}\text { Mean Bank } \\
\text { Spread }\end{array}$ & $\begin{array}{c}25 \text { th } \\
\text { Percentile } \\
\text { Bank Spread }\end{array}$ & $\begin{array}{c}\text { 75th } \\
\text { Percentile } \\
\text { Bank Spread }\end{array}$ & $\begin{array}{l}\text { Mean Total } \\
\text { Cost }\end{array}$ & $\begin{array}{c}\text { 25th } \\
\text { Percentile } \\
\text { Total Cost }\end{array}$ & $\begin{array}{c}\text { 75th } \\
\text { Percentile } \\
\text { Total Cost }\end{array}$ \\
\hline \multicolumn{7}{|l|}{ All Issues } \\
\hline Electrical & 3.67 & 2.57 & 4.55 & 5.08 & $3.6 \mathrm{l}$ & 7.00 \\
\hline \# firms & 13 & - & - & 12 & - & - \\
\hline \# observations & 21 & - & - & 20 & - & - \\
\hline Manufacturing & 3.90 & 2.94 & 4.35 & 5.30 & 2.78 & 7.60 \\
\hline \# firms & 19 & - & - & 15 & - & - \\
\hline \# observations & 30 & - & - & 20 & - & - \\
\hline \multicolumn{7}{|c|}{ Issues Less Than 1 Million } \\
\hline Electrical & 3.94 & 3.49 & 4.26 & 5.24 & 4.00 & 6.72 \\
\hline \# firms & 4 & - & - & 3 & - & - \\
\hline \# observations & 7 & - & - & 3 & - & - \\
\hline Manufacturing & 3.45 & 2.78 & 3.86 & 5.29 & 3.33 & 6.92 \\
\hline \# firms & 10 & - & - & 10 & -- & - \\
\hline \# observations & 18 & - & - & 15 & - & - \\
\hline \multicolumn{7}{|c|}{ Firms with 1913 Capital Less Than 2 Million } \\
\hline Manufacturing & 4.11 & 3.57 & 4.80 & 5.93 & 3.33 & 8.80 \\
\hline \# firms & 3 & - & - & 5 & - & - \\
\hline \# observations & 6 & - & - & 5 & - & - \\
\hline
\end{tabular}

Source: Saling's Borsen Jahrbuch 1913.

Notes: Percentages of bankers' commissions (spreads) is the difference between the amount paid for an issue by purchasers and the amount paid by the bankers to the issuing firm divided by the total amount paid for the issue. Percentage of total costs is the net funds raised by the firm (net of all expenses, including taxes, printing costs, and commissions) divided by the amount paid for the issue. Data are for firms that reported such information in Saling's Borsen Jahrbuch in the electrical industry (electrical equipment producers and power plant operators) and the metal manufacturers industry. The sample includes all reporting firms in the electrical industry and all reporting firms whose names begin with $A$ through $K$ for the metals manufacturing industry.

cluded all costs and that reported commissions generally did not include fees other than commissions.

Data on commissions for common stock issues earned by German banks from 1893 to 1913 are provided in table 8.7. The sample of firms for which data were collected include all reporting firms in the electrical industry (which includes manufacturers of electrical equipment and operating power plants) and firms in the metal manufacturing industry whose names begin with the letters $\mathrm{A}$ through $\mathrm{K}$. Both of these industries are important producers of new products, and both are central to the second industrial revolution. The metal manufacturing industry includes many small firms, while the electrical industry is dominated by large firms, so together these two industries can provide some evidence on the role of firm size and issue size in determining bankers' commissions. For both industries, I divide the sample into small and large issues (less than or greater than 1 million marks, which equals $\$ 220,000$ ). For 
metals, I also report data for firms with small total capital in 1913 (less than 2 million marks). The difference between average spreads and average total costs is 1.41 percent for the electrical industry and 1.40 percent for metal manufacturing, which suggests that taxes and physical costs were generally included in total costs and not in commissions. Bankers' commissions averaged 3.67 percent for the electrical industry and 3.90 percent for metal manufacturing. Commissions on small and large issues are essentially the same. Although small metals issues show lower average costs, the difference is not statistically significant for this small sample. Metals firms with low total capital had average commissions of 4.11 percent, compared to 3.90 percent for the industry as a whole. Again, this difference is small and not statistically significant. Overall, these data support the view that commissions on common stock were roughly 3-5 percent, and that they did not vary much by industry, firm size, or size of issue.

For the United States, firm-level data on bankers' commissions are not generally available for the pre-World War I period. Indeed, the dearth of equity issues in the United States historically made it difficult for the Securities and Exchange Commission to locate data on common stock spreads prior to 1936. Even with respect to bonds and preferred stock, the SEC's retrospective study begins only in the 1920s. Despite this problem, it is possible to gauge roughly the range of commission charges during the pre-World War I period using data from the later period and a few observations on individual transactions from the pre-World War I period. Data on bankers' spreads for bonds and preferred stocks during the 1920 s and common stock spreads for the 1930 s reported in table 8.8 are a reasonable, and possibly a conservative, measure of their preWorld War I values. There is little evidence of change in preferred stock or bond spreads from the 1920 s to the mid-1930s, so there is little reason to believe that spreads were influenced by the Glass-Steagall separation of commercial and investment banking. ${ }^{19}$ As argued above, the fundamental restrictions on universal banking were regulations that fragmented the banking system, and these were in place long before Glass-Steagall. Moreover, there is some discussion of spreads for the pre-World War I period that confirms this view. Brandeis (1914, 94-99) discusses bankers' spreads at length in his attack on the money trust. He notes that Morgan's spread exceeded 20 percent for the organization of U.S. Steel, and was 25 percent for underwriting the "Tube Trust." More generally, Brandeis writes: "Nor were monster commissions limited to trust promotions. More recently, bankers' syndicates have, in many instances, received for floating preferred stocks of recapitalized industrial concerns, one-third of all common stock issued, besides a considerable sum in cash. And for the sale of preferred stock of well established manufacturing

19. Calomiris and Raff (1993) report data on common stock spreads from the Lehman Brothers deal books and argue, based on these data, that common stock spreads were essentially the same in the $1920 \mathrm{~s}$ and $1930 \mathrm{~s}$. 
Bankers' Spreads in the United States before World War II

\begin{tabular}{|c|c|c|c|c|c|c|}
\hline & \multicolumn{3}{|c|}{$\begin{array}{c}1925-29 \\
\text { (\% of issue) }\end{array}$} & \multicolumn{3}{|c|}{1930 s (\% of issue) } \\
\hline & Common & Preferred & Bonds & Common & Preferred & Bonds \\
\hline Issues $<\$ 5$ million & & & & $(1935-38)$ & $(1935-38)$ & $(1935-38)$ \\
\hline Total costs & NA & 8 & 6 & 18 & 10 & 5 \\
\hline Compensation & NA & 7 & 5 & 16 & 9 & 4 \\
\hline Other expenses & NA & l & 1 & 2 & l & l \\
\hline \# of issues & NA & 96 & 423 & 241 & 206 & 210 \\
\hline All to public, IBs $^{\mathrm{a}}$ & & & & (1938) & (1938) & (1940) \\
\hline Total costs & & & & 22 & 12 & 3 \\
\hline Compensation & & & & 20 & 11 & 2 \\
\hline Other expenses & & & & 2 & l & 1 \\
\hline \# of issues & & & & 68 & 37 & 76 \\
\hline All to public, IBs ${ }^{a}$ & & & & (1938) & $(1938)$ & $(1940)$ \\
\hline Total cost, underwritten issues & & & & 23 & 4 & 3 \\
\hline \# of issues & & & & 16 & 9 & 31 \\
\hline Total cost, best efforts & & & & 21 & 14 & 16 \\
\hline \# of issues & & & & 52 & 28 & 1 \\
\hline
\end{tabular}

Source: Securities and Exchange Comimssion 1940, 1941.

"All issues of securities to the public transacted through investment bankers.

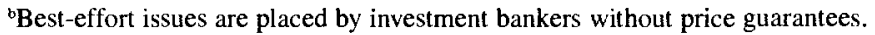

concerns, cash commissions (or profits) of from $71 / 2$ to 10 percent of the cash raised are often exacted. On bonds of high-class industrial concerns, bankers' commissions (or profits) of from 5 to 10 points have been common" (95). These figures are similar to the numbers for the 1920s and mid-1930s reported in table 8.8 .

Interestingly, the spreads for common stock far exceed those for preferred stock, which in turn far exceed those for bonds. This is what one would expect if the spreads largely represent compensation for information costs incurred in arranging the issues. The underwriting (insurance) aspect of the investment bankers' services do not explain the differences in the spreads for different types of securities. In fact, best-effort flotations, on which there is no underwriting risk, show larger commissions on average than underwritten flotations. This typically is explained by the fact that best-effort flotations involve riskier firms (Friend 1967, 39) and therefore entail greater due diligence and marketing costs.

It is worth emphasizing how large these spreads are. A 20 percent spread indicates that a firm only receives 80 cents for every dollar of claims it issues. This places a substantial cost on investments, especially by young, unseasoned firms. An investment opportunity must be able to generate enough income to pay interest or dividends to claimants and compensate existing shareholders by an amount (in present value) in excess of 20 percent of the project's cost. 
There is corroborating evidence that external finance costs placed wedges of this magnitude between the social and private benefits of pursuing investment projects. Calomiris and Hubbard (1994) find that in the mid-1930s roughly a quarter of publicly traded firms in the United States had a cost differential between internally and externally generated funds in excess of 20 percent. They used a firm's dividend-payout reaction to the undistributed profits tax of 1936-37 to measure this shadow price differential. In a study of nineteenthcentury profits, Atack and Bateman (1992) find large and widening differences in profit rates between small and large manufacturing firms in the United States of a similar order of magnitude, which suggest barriers to entry and geographic immobility of capital for financing small and medium-sized firms in manufacturing. ${ }^{20}$

The data reported in tables 8.7 and 8.8 indicate a substantially lower average cost of bringing equities to market in Germany, which helps to explain the relative dearth of equity issues in the United States shown in table 8.5. German bankers' spreads on equity were less than one-fourth those in the United States. Small German firms were able to issue equity for less than the cost large American corporations paid for issuing bonds. Interestingly, in Germany, spreads did not vary by size as they did in the United States. This is consistent with viewing universal banking networks (which permit internal marketing of new issues) as economizing on fixed costs of marketing stock issues.

One possible explanation for this difference is that German banks earned large anticipated capital gains on underwritings in addition to spreads. While a detailed examination of this proposition must await further research on firmlevel data, an analysis of aggregate data suggests capital gains were small. Riesser $(1911,466)$ cites data on income earned from the sum of commissions and capital gains on securities transactions in 1903 published in the Kölnische Zeitung (see also Whale 1930, 26). A rough measure of capital gains earned by banks on securities holdings can be derived by combining this estimate with Eistert's (1970) estimates of total securities issued to derive a measure of total income from spreads and capital gains as a ratio of total issues. These data are reported in table 8.9. Using additional data on the composition of securities issues from Eistert $(1970,103)$, and the estimates of bankers' commissions, one can place some bounds on the rate of capital gains. To do so requires an assumption about banks' relative earnings from underwriting government bonds, corporate bonds, and equity. I assume that the banks' earnings from commissions and capital gains on equities are double those for corporate bonds, and that earnings on government bonds are 1 percent. Under these as-

20. Average manufacturing profit rates of firms rose form 18 percent in 1850 to 34 percent in 1880, while profit rates weighted by capital fell from 16 percent to 15 percent. In the South in 1880 , unweighted profit rates were 43 percent, compared to 30 percent in the North. Clearly, for large numbers of small and medium-sized firms, profit rates did not converge over time within or across regions during this period. Differences of 20 or 30 percent in profit rates across firms were common throughout the period $1850-80$. 
Table 8.9

Estimate of German Banks' Capital Gains Rate from Securities Underwritten in 1903

Gross profits from commissions and capital gains

Total securities placed

55.7 million marks

Average spread

1,285. I million marks

German government bonds placed

Bonds placed (excluding German government)

Stocks placed

Assumed ratio of profit rates from stocks and corporate bonds

Assumed profit rate for government bonds

0.043

Implied average profit rate for corporate bonds

343.3 million marks

597.1 million marks

344.7 million marks

Implied average profit rate for stocks

2

0.01

0.040

0.080

Implied capital gain rate for stocks given $4.0 \%$ commission $\quad 0.040$

Sources: Securities placed are from Eistert 1970, 103. Gross profits are from Kölnische Zeitung, as cited in Riesser 1911, 466.

sumptions, the total income earned from commissions plus capital gains on equity issues in 1903 was 8 percent of the amount issued. Given the estimate of 4 percent for equity commissions, this implies a 4 percent capital gain on equity issues. Thus, it seems that one cannot explain the difference between U.S. and German commissions on equity by appeal to offsetting capital gains by German underwriters.

The U.S.-German underwriting-spread comparison illustrates more than the high cost of capital in the United States. It also indicates that rent extraction is an unlikely explanation of high underwriting costs in the United States. German banking was at least as concentrated and powerful an industry as the purported money trust of the United States. Yet their spreads were quite small. Thus, higher average U.S. spreads likely reflected higher underlying costs of bringing issues to market in the United States. The fact that spreads for small firms and small issues in Germany were the same as for large firms is also significant. In the United States, smaller firms suffered significantly larger spreads, as shown in table 8.10, and firm size has also proven important in cross-sectional regression analysis of spreads (Mendelson 1967). Thus, the lower cost of equity issues in Germany relative to the United States affected the financing cost of small firms even more than shown by comparisons of average commissions. This lends credence to the view that "time-consistency" advantages and lower information costs (which are most relevant for small, growing firms) are an important part of the explanation for why German commissions were lower.

Additional evidence from time-series and cross-sectional analysis of bankers' spreads in the United States also suggests that spreads were more a function of information cost than of rent. First, the fact that spreads were larger for preferred stock than for bonds, and largest for common stock, is consistent with the information-cost interpretation of the spreads, and not with the rentextraction interpretation. As Miller $(1967,157)$ shows, concentration in Amer- 
Table 8.10

Costs of Flotation of Primary Common Stock Issues Offered through Dealers, Post-World War II

\begin{tabular}{llcc}
\hline Dates & Size of Issue & Number of Issues & Average Cost as \% Proceeds \\
\hline $1935-38$ & Issue $<\$ 5$ million & 241 & 18 \\
$1945-49$ & Issue $<\$ 5$ million & 208 & 15 \\
$1951-55$ & Issue $<\$ 5$ million & 178 & 15 \\
$1963-65$ & Issue $<\$ 5$ million & 369 & 12 \\
1940 & Issue $>$ \$5 million & 11 & 12 \\
$1945-49$ & Issue $>\$ 5$ million & 49 & 8 \\
$1951-55$ & Issue $>$ \$5 million & 52 & 6 \\
$1963-65$ & Issue $>\$ 5$ million & 107 & 7 \\
\hline
\end{tabular}

Sources: Securities and Exchange Commission 1940, 1941, 1970.

ican investment banking has always been highest in bond underwriting, yet bonds have always enjoyed the lowest spreads. Second, as table 8.10 shows, common stock spreads fell most dramatically from the 1930s to the early 1960 s, but this was not associated with increased competition. Miller (1967, 163) finds that the only reduction in concentration of investment banking over this period occurred in the bond market, in which spreads fell least. Third, cross-sectional studies of stock and bond spreads (Cohan 1961; Mendelson 1967) find substantial evidence linking variation in spreads to "quality" or information-related variables. For example, bond spreads increase with bond yields. Stock spreads are higher for issues that include "extra inducements," and for issues with lower-quality underwriters, which Miller (1967) and Mendelson $(1967,445,474)$ associate with lower-quality firms. The most plausible explanation for the technological change that lowered spreads over time was the increase in bulk sales to institutional investors, which reduced the signaling and marketing costs of appealing to a widely dispersed group of investors (Haven 1940; Mendelson 1967, 413-19). The rise of direct placements after World War II also provided an alternative to syndication. These innovations were a partial substitute for a universal banking system, in which the universal bank would have directly linked issuers and holders.

\subsubsection{Financial Returns and Access to Securities Markets}

Arguments about the effects of higher information and control costs in industrial finance in the United States relative to Germany do not have clear empirical implications for expected returns on financial instruments. On the one hand, if universal banking in Germany were superior as a mechanism for limiting ex ante lemons discounts on securities, for disciplining firms, and for managing corporate distress in default states, then more high-risk firms would be admitted to securities markets, and more financial claims would be held in the form of riskier junior instruments like stocks. On the other hand, if banks are very good at reducing lemons problems, disciplining firms, and organizing 
workouts, then to the extent that these risks are systematic, overall risk on traded assets could be lower for Germany. ${ }^{21}$ Thus, depending on which of these two effects dominates, returns on financial assets could be higher or lower under universal banking.

Comparisons of interest rate and yield "spreads"-returns in excess of the riskless interest-rate benchmark within each country-provide more information than comparisons of nominal returns across countries. There are problems in making inferences from comparisons of returns on financial assets across countries. Imperfect international capital market integration for riskless assets, and different expectations of commodity price movements across countries make direct comparison of nominal yields and returns problematic measures of the banking system's effect on real costs of industrial finance. The spreads between riskless public bonds and private securities returns in both countries remove elements of difference attributable to the relative supply of savings.

A problem in relating differences in returns spreads to structural differences across countries is the need to infer average ex ante returns on equity from average ex post returns. Under the assumption that expected and actual returns were roughly equal on average, ex post returns can serve as a gauge of expected stock returns. The shorter the sample period, the more dubious this assumption becomes. Furthermore, it is not clear whether, under a specie standard, nominal or real stock returns provide a better measure of expected returns. If commodity prices under a specie standard follow a random walk (possibly with long-run mean reversion, as suggested by Klein 1975, Rockoff 1984, and Barsky 1987), nominal averages of returns may provide a superior measure of expected real returns. For this reason, and because of the availability of such data, I report nominal spreads.

Table 8.11 reports data on spreads between government bond yields and private securities returns (bond yields and stock returns) for Germany and the

21. According to the capital asset pricing model, the average return on the market portfolio will compensate for systematic (nondiversifiable) risk. If the absence of universal banking increases overall systematic risk for stocks, then it should increase expected stock returns, ceteris paribus. Increased systematic risk could result, in theory, from at least three causes. First, under asymmetric information, the stock value of firms subject to borrowing constraints will vary with the shadow cost of external finance, which in turn will increase in times of low cash flow (Myers and Majluf 1984; Gale and Hellwig 1985; Brock and LeBaron 1990). Since firms' cash flows are correlated over the business cycle, this will induce greater correlation in stock returns among firms in an economy without universal banking. Second, expected costs of financial distress also increase firm risk. Again, the probability of financial distress varies systematically for all firms over the business cycle. If universal banking reduces distress costs, then it will decrease systematic risk in the portfolio of stocks. Third, managerial discipline may be more important during certain phases of the business cycle, since managers' incentives to cheat vary with the state of the economy. For example, under limited liability, managers who hold stock in their firm may chose to take on excessive risk in bad times (Jensen and Meckling 1976; Myers 1977; Calomiris and Kahn 1991). As in the other examples, this will induce greater systematic risk for the stock portfolio. 


\begin{tabular}{cccccccc}
\hline & $\begin{array}{c}(1) \\
\text { Government } \\
\text { Bond Yield }\end{array}$ & $\begin{array}{c}(2) \\
\text { Corporate } \\
\text { Bond Yield }\end{array}$ & $\begin{array}{c}(3) \\
\text { Stock } \\
\text { Return }\end{array}$ & $\begin{array}{c}\text { Private-Public } \\
\text { Bond Spread } \\
(2)-(1)\end{array}$ & $\begin{array}{c}\text { (5) } \\
\text { Stock Spread } \\
(3)-(1)\end{array}$ & $\begin{array}{c}\text { Private } \\
\text { Portfolio } \\
\text { Returns }\end{array}$ & $\begin{array}{c}\text { Portfolio } \\
\text { Spread } \\
(6)-(1)\end{array}$ \\
\hline $\begin{array}{c}\text { Germany } \\
\quad 1883-1912\end{array}$ & 3.29 & 3.65 & 8.30 & 0.36 & 5.01 & 7.84 & 4.55 \\
$\begin{array}{c}\text { United States } \\
1880-99\end{array}$ & 2.68 & 4.65 & 5.39 & 1.97 & 3.24 & 5.02 & 2.52 \\
$1900-1913$ & 2.32 & 5.00 & 6.80 & 2.68 & 4.48 & 5.90 & 3.57 \\
\hline
\end{tabular}

Sources: Data on stock returns is derived from Snowden 1990, 414-15. U.S. corporate bond yields for 1880-99 are Macaulay`s (1938) unadjusted railroad series, as reported in U.S. Department of Commerce 1975, 1003. Hickman's $(1958,81)$ data on bond yields for 1900-1909 are used for the later period. U.S. government bond yields are from Homer and Sylla 1991, 316,343. German bond yields and nominal stock returns are from Tilly 1992, 103. German government bond yields are taken from Homer and Sylla 1991, 260-61, 504.

Notes: For the United States, equal weights are given to stock and bond holdings in the portfolio, consistent with the evidence in table 8.5. In comparing realized returns on portfolios with yields, it is assumed that ex post stock returns on average were close to ex ante returns, which cannot be measured.

United States in two forms: simple spreads between government bonds and private stocks and bonds, and weighted spreads (using the proportion of stocks and bonds as weights) between private securities and government bonds. The weighted spread is useful as a measure of the total return on corporate assets (to control for differences in bond or stock spreads resulting from different corporate leverage in the United States and Germany).

These data come from a variety of sources. U.S. stock returns for a market basket of stocks are reported in Snowden 1990, 387. Bond yields for U.S. government bonds are from Homer and Sylla 1991, 316, 343. Private bond yields prior to 1900 are the unadjusted railroad bond series from Macaulay 1938. For the period after 1900, by which time other corporate bonds had become important in capital markets, I use Hickman's $(1958,81)$ data on average ex ante corporate bond yields for 1900-1909 as the measure of private bond yields. ${ }^{22}$ For German portfolio returns, I use Tilly's $(1992,103)$ data on industrial bond yields and returns on industrial stocks. German government bond yields are taken from Homer and Sylla 1991, 260-61, 504.

The differences between American and German returns spreads in table 8.11 suggest larger financial portfolio risk associated with German financial assets, which mainly reflects the larger share of equity in German finance, but also

22. During this period, government bonds had a "circulation privilege," meaning that they could be used as backing for national banknotes issued by national banks. Some researchers have avoided using these bond yields as measures of nominal riskless returns because of a possible liquidity premium making their yields artificially low. Calomiris (1988, $726 \mathrm{n}$. 9) argues against this view on theoretical grounds, and Snowden $(1990,388 \mathrm{n}$. 10) argues against it on empirical grounds. 
the higher returns on equity in Germany. As noted at the outset, such a finding may indicate information-cost advantages that brought higher-risk firms into the market for traded securities under universal banking. The facts that the government-corporate bond yield spread is larger in the United States and that the stock and portfolio spreads are larger in Germany are consistent with German firms achieving rapid access to equity markets. By themselves, however, the data on spreads do not prove universal banking was advantageous, since an alternative interpretation of high stock returns in Germany is higher economywide risk in Germany. One way to sort out whether high financial asset returns reflected well on Germany's financial system is to compare traded portfolio risks and underlying total economic risks in the United States and Germany. If universal banking allowed riskier securities to enter financial markets (the sanguine view of universal banking), then risk differences in traded assets between the two countries should exceed underlying economic risk differences for all assets.

One measure of economywide asset risk is the rate of business failure. Using the Black-Scholes model of option pricing, bankruptcy risk is a function of underlying asset risk (sigma) and the ratio of debt to the value of assets. Holding the debt-to-asset ratio constant, a higher risk of bankruptcy indicates a higher asset risk. In fact, debt-to-asset ratios were similar in the two countries overall, despite the higher equity-to-debt ratio in German traded securities. In the United States, debt was 30 percent of total assets in 1990 (Goldsmith 1985, 324-25), while in Germany debt was 32 percent in 1913..$^{23}$ Thus failure-rate differences are a good proxy for differences in asset risk between the two economies. Table 8.12 reports data on liabilities of failed businesses in dollars and marks for 1900-1908 (the years for which I was able to locate German data on liabilities of failed businesses), and the ratio of the average annual level of these to national assets in 1912/13. Because Dun and Bradstreet's data on liabilities of U.S. commercial and industrial failures exclude railroads and banks, I have added estimates of those numbers from other sources. This comparison of liabilities of failures relative to national assets gives some sense of the relative magnitude of overall risk in the two economies. The all-inclusive ratio for Germany is slightly lower than that of the United States, and when bank failures are omitted from the U.S. series, the two ratios are identical. This lends support to the view that universal banking lowered the threshold for admission into securities markets, and stock markets in particular. The risk on traded assets in Germany was much higher than in the United States, even though the underlying economywide risk was essentially the same in the two economies. This is consistent with the proposition that lower information and control costs under universal banking allowed greater participation of high-risk firms in securities markets.

23. The German debt-to-asset ratio is calculated using definitions from Goldsmith's U.S. calculations for Germany $(1985,225,324-25)$. 
Table 8.12

Risk of Failure in Germany and the United States

(liabilities of failures/national assets)

Liabilities of Failed Businesses

\begin{tabular}{rrrrr}
\hline & & \multicolumn{3}{c}{$\begin{array}{c}\text { United States } \\
\text { (millions of } \$ \text { ) }\end{array}$} \\
\cline { 3 - 5 } & $\begin{array}{c}\text { Germany } \\
\text { (millions of marks) }\end{array}$ & Dun and Bradstreet & Railroads & Banks (assets) \\
\hline 1900 & 188 & 138 & 0 & 19 \\
1901 & 224 & 113 & 27 & 15 \\
1902 & 392 & 117 & 13 & 8 \\
1903 & 319 & 155 & 0 & 9 \\
1904 & 398 & 144 & 7 & 32 \\
1905 & 499 & 103 & 31 & 21 \\
1906 & 346 & 119 & 15 & 9 \\
1907 & 302 & 197 & 27 & 18 \\
1908 & 311 & 222 & 74 & 208 \\
$1901-8$ & 2,979 & 1,308 & 194 & $339(275=$ liabilities) \\
\hline
\end{tabular}

National Assets

\begin{tabular}{lll}
\hline 1912 & 301,500 \\
1913 & 639,300 & \\
\hline
\end{tabular}

Average Liabilities of Failures, 1900-08/National Assets, 1912 or 1913

0.00052

0.00065

0.00055 (omitting bank failures)

Sources: Dun and Bradstreet's series on liabilities of failed businesses (U.S. Department of Commerce 1975, 912) for the United States excludes railroads and banks. Railroad bonds in default (Hickman 1960, $250)$ is a lower bound of omitted railroad liabilities. Bremer $(1935,27)$ reports assets of all failed banks. Calomiris (1993, table 4) reports the liability-to-asset ratio of all U.S. banks in 1904 (0.81), which is assumed to hold for failed banks for 1900-08. German liabilities of all failed firms is reported in Viertel Jahreshefte zur Statistik des deutschen Reiches, sec. 4, various issues. Goldsmith $(1985,226,301)$ provides data on national assets for both countries.

\subsubsection{Summary}

Germany and the United States both achieved substantial industrial growth from 1870 to 1913. Comparisons of financial system performance suggest that German industrial growth was helped, and American growth was hindered, by their respective financial systems. Relatively high German ratios of financial assets and physical capital to GNP, and the high proportion of equipment in the German capital stock, are at least partly explained by lower costs of finance for industrial firms. These lower costs of finance are reflected in greater access to equity markets in Germany for risky industrial firms and their bankers, and lower costs of bringing securities to market. The low cost of floating equity issues in Germany, particularly for small firms, is especially revealing. Overall, the statistical comparison of German and American financial systems confirms 
qualitative historical and theoretical analysis that has linked universal banking to low costs of industrial finance. Unfortunately, much of the analysis that has been undertaken here has been restricted to aggregate comparisons. Comparative industry- and firm-level studies of finance costs are the obvious next step, and an important step before reaching definitive conclusions about the size of the contribution of German superiority in industrial finance to industrial performance.

\subsubsection{The Inverted Histories of German and American Industrial Finance}

Perhaps surprisingly, the United States enjoyed a universal banking system of a sort long before universal banking was established in Germany. As Davis (1957, 1960) and Lamoreaux (199lb) emphasize, New England's antebellum banks were a primary source of funding for New England industrialists. Just as in Germany, the links between industry and banking were very close. The banks were chartered to provide credit to their industrialist founders. In many cases, the officers and directors of the banks were their principal borrowers. New England bank stock was widely held by outsiders, and banks had much higher ratios of equity to assets than banks in other regions. In the mid-1850s, Massachusetts banks' capital and surplus relative to assets was roughly double that of New York and Pennsylvania (Calomiris, 1991a, 198). ${ }^{24}$ As Calomiris and Kahn (1990) show, stock returns were relatively low in New England compared to other regions. New England banks may have been able to attract large numbers of outside stockholders and pay lower returns on equity than other banks because their institutional arrangements mitigated information problems. Each bank's borrower-insiders had incentives to monitor each other, and interbank relationships ensured monitoring among members of the Suffolk system (the New England payments clearing system run by Boston banks) and among commercial banks and savings banks (which financed much of commercial banks' activities). ${ }^{25}$

Lamoreaux (1991b, 1994) documents the demise of this system. By 1900, New England's banks had identical capital ratios to other regions' banks ( $\mathrm{Ca}$ lomiris 199la) and had changed toward financing more commercial undertakings and toward lending to bank outsiders. Calomiris (1993) interprets these changes as reflecting the growing mismatch between ever-larger scaled firms, and inherently small unit banks. As firms became larger, small banks found it

24. In Calomiris 1991a, I argued that Boston and Providence banks were mainly responsible for the difference in capital ratios between New England and other states. While it is true that Providence had unusually high capital ratios, even for New England, I overstated the difference between city and country banks in New England. My claim that "the capital of Massachusetts banks falls from 51 percent to 33 percent" (199) when one removes Boston banks from the sample was based on a calculation error. In fact, city and country banks in Massachusetts had nearly identical capital ratios.

25. It is interesting to note the many similarities to the German system, including the close relationships between banks and firms, and the use of savings institutions as investors in industrial banks. Savings cooperatives (kreditgenossenschaften) were large depositors in the German credit banks (Riesser 1911, 198-202). 
increasingly difficult to satisfy the investment-financing needs of customers, given the desirability of maintaining a diversified loan portfolio. As Lamoreaux (1991a) shows, many New England banks wanted to respond to the growing scale of firms, and the economies of scope and scale from universal banking, by merging. When banks were able to merge, their profits increased substantially. Ultimately, however, national and state banking laws stood in the way of bank mergers or branching, as unit bankers blocked attempts to liberalize branching laws and prevented attempted mergers.

Over this same period (1850-1900), a German financial system dominated by private bankers transformed into the premier universal banking system of the world. Early examples of success in chartering limited-liability industrial banks elsewhere in Europe (notably the Credit Mobilier) and legal changes in Germany allowing limited-liability banking on a national scale paved the way for financial innovations that spread rapidly after 1870 (Tilly 1966, 1992; Kindleberger 1984). In contrast to the United States, where banking powers were limited compared to the growing powers of industrial corporations during the Progressive Era, Germany was relatively liberal in its treatment of banking powers and restrictive of nonfinancial firms (Tilly 1982, 653).

\subsection{The Persistence of Inefficient Regulation}

Thus far I have argued from comparisons of German and American financial systems that differences in banking regulation inhibited the development of an optimal mechanism for corporate finance in the United States. Restrictions on branching and consolidation restricted the size of banks. These became important constraints on the development of universal banking during the late nineteenth century as the size of firms and their borrowing needs expanded. The Clayton Act of 1914 may have further hampered America's ability to develop universal banking, by limiting bankers' influence over client firms through interlocking boards of directors. Thus, universal banking of the German type was never possible in the United States, even before Glass-Steagall restrictions on underwriting by affiliates of commercial banks. ${ }^{26}$

Nevertheless, during the 1920s, the U.S. financial system began to "converge" to a system of larger banks operating branches and performing combinations of commercial banking, investment banking, and trust activities like

26. Kroszner and Rajan (1994), in their study of differences between the bond-underwriting activities of investment banks and investment banking affiliates of commercial banks, find little evidence for greater efficiency of affiliates. The experience of the $1920 \mathrm{~s}$ in the United States indicates little, however, about the advantages of universal banking. Removing Glass-Steagall prohibitions along with repealing the Clayton Act and removing branching restrictions on banks (which would permit U.S. banks to operate true universal banks) would likely have a much larger positive effect. Furthermore, investment banking affiliates in the 1920 s were very new enterprises. Given more time and experience, their performance might have improved. 


\section{Table 8.13}

Progressive Developments in U.S. Banking and

Corporate Finance, 1920s

\begin{tabular}{|c|c|c|c|c|c|}
\hline \multicolumn{6}{|c|}{ Banking Trends } \\
\hline & $\begin{array}{c}\text { \# Banks } \\
\text { in Securities }\end{array}$ & $\begin{array}{l}\text { Bank } \\
\text { Mergers }\end{array}$ & $\begin{array}{c}\text { \# of Banks } \\
\text { Absorbed }\end{array}$ & $\begin{array}{c}\text { Branching } \\
\text { Banks (Branches) }\end{array}$ & $\begin{array}{l}\text { Bank Short-Term Loans } \\
\text { to Nonfinancial Corporations } \\
\text { (millions of \$) }\end{array}$ \\
\hline 1910 & & 127 & 128 & $292(548)$ & \\
\hline 1911 & & 119 & 119 & & \\
\hline 1912 & & 128 & 128 & & 3.902 \\
\hline 1913 & & 118 & 118 & & \\
\hline 1914 & & 142 & 143 & & \\
\hline 1915 & & 154 & 154 & $397(785)$ & \\
\hline 1916 & & 134 & 134 & & \\
\hline 1917 & & 123 & 123 & & \\
\hline 1918 & & 119 & 125 & & \\
\hline 1919 & & 178 & 178 & & \\
\hline 1920 & & 181 & 183 & $530(1.281)$ & \\
\hline 1921 & & 281 & 292 & $547(1,455)$ & \\
\hline 1922 & 277 & 337 & 340 & $610(1.801)$ & 8.834 \\
\hline 1923 & 314 & 325 & 325 & $671(2.054)$ & \\
\hline 1924 & 372 & 350 & 352 & $706(2.297)$ & \\
\hline 1925 & 413 & 352 & 356 & $720(2.525)$ & \\
\hline 1926 & 464 & 429 & 429 & $744(2.703)$ & \\
\hline 1927 & 493 & 543 & 544 & $740(2.914)$ & \\
\hline 1928 & 561 & 501 & 507 & $775(3.138)$ & \\
\hline 1929 & 591 & 571 & 575 & $764(3.353)$ & 10.699 \\
\hline
\end{tabular}

Gross Sales of Corporate Securities Issues. Annual Averages (billions of \$)

\begin{tabular}{lcccc}
\hline & Stock & Industrial Stocks & Corporate Bonds & Industrial Bonds \\
\hline $1901-12$ & 0.5 & 0.15 & 0.9 & 0.11 \\
$1913-22$ & 0.7 & 0.40 & 1.3 & 0.35 \\
$1923-27$ & 1.6 & 0.64 & 3.6 & 0.78 \\
$1928-29$ & 6.5 & 2.70 & 3.4 & 0.68 \\
\hline
\end{tabular}

Sources: Corporate finance data are from Friend 1967. 68. Data on banks operating securities affiliates are from Peach 1941. 83. Bank merger data are from Chapman 1934. 56. Bank branching data are from Board of Governors of the Federal Reserve System 1976. 297. Bank lending to nonfinancial firms is from Goldsmith 1958, 339 .

German universal banks. As shown in table 8.13, the progressive trend in the United States in the 1920s is visible in many measures, including bank branching and consolidation, bank financing of industry, the development of long-term lending from banks to industrial enterprises, and the growing proportion of equity finance relative to debt. Consistent with the argument that economies of scope in universal banking are enhanced by large-scale banking, the dramatic increase in bank involvement in securities markets in the $1920 \mathrm{~s}$ 
coincided with a dramatic increase in consolidation and branching by banks. Investment banking affiliates of national banks played an important part in these progressive trends. They operated on a larger scale than their investment bank competitors, performed a greater variety of functions, and often charged lower commissions to customers in securities transactions (Preston and Finlay 1930a, 1930b). While investment banking affiliates did not lead to universal banking of the German kind (branching restrictions still applied in many states and branching was not allowed across state lines), the relaxation of branching restrictions in the 1920 s was associated with a trend toward greater bank involvement in underwriting. Even in nonbranching states like Illinois, concentration of deposit and trust activities in large Chicago banks encouraged bank underwriting (Bureau of Business Research 1928).

In the wake of the Great Depression of the 1930s, however, the United States chose to limit the scope of banking with the restrictive Banking Acts of 1933 and 1935, to discourage bank consolidation through mergers, and to eschew the relaxation of branching laws in favor of deposit insurance as a means to insulate small banks and their depositors from the threat of bank failure and systemic panic. This reversal in direction in the 1930s is hard to understand on efficiency grounds and seems best viewed as the last and most successful in a long series of attacks by populist forces on large-scale banking. It also suggests that, with respect to financial regulation, the United States is singularly incapable of learning from the past.

Explanations for the change in direction that occurred in the wake of the Great Depression have been suggested by Calomiris and White (1994). They argue that politicking by powerful unit bankers (Stigler 1971) does not explain the change in direction in banking regulation. The power of unit bankers was at an all-time low in 1930 due to the many failures of small banks. Furthermore, deposit-insurance legislation won by unit bankers from 1908 to 1920 in eight states was responsible for financial devastation in the states that had passed such legislation (Calomiris 1989, 1990, 199lb). Calomiris and White (1994) argue that despite these facts the credibility of large bankers, and of large banks operating securities affiliates, was undermined by the accusations of the Pecora hearings and by the political campaigning of Steagall and others who managed to portray big banking, and links between securities markets and banks, as the cause of the Great Depression. Furthermore, unprecedented depositor losses galvanized support for deposit insurance. Once the Great Depression legislation was passed, it resuscitated unit banks as a powerful special interest resisting reform or repeal of Great Depression protections.

Since the Great Depression, other factors may have worked against repeal of Depression-era regulations. Endogenous technological changes induced by inefficient regulations may have helped to perpetuate regulations by reducing their costs. For example, technological changes that produced declines in underwriting costs in the United States in the 1960s, notably the increased role of private placements and of securities purchases in bulk by institutional in- 
vestors, may have lessened the pressure to repeal the separation between commercial and investment banking. Another example is the rise of finance companies and the modern commercial paper market, beginning in the 1960s, and the development of the relatively unregulated bank CD market, which kept Regulation Q restrictions from significantly increasing industrial finance costs. Today, the effects on financing costs from increased capital requirements and other regulatory costs on banking are mitigated by the growth of loan sales markets and asset securitization.

Of course, the past is not always a perfect guide to the future. Perhaps pressure from globalization of finance has lowered the tolerance for poor regulation in the United States. There is much discussion about expanding bank powers to branch and provide a wide array of products, and some limited progress has been made on both fronts. New entrants from abroad have encouraged these trends. From this perspective, recent international coordination in bank regulation (the Basle capital standards) is a particularly interesting development. It may signal the erosion of domestic autonomy in bank regulation and greater international competition, or it may be a harbinger of agreements among governments to limit international competition and protect regulatory autonomy. Time will tell.

\section{References}

Atack, Jeremy, and Fred Bateman. 1992. Did the United States Industrialize Too Slowly? Working paper, Vanderbilt University.

Barsky, Robert B. 1987. The Fisher Hypothesis and the Forecastability and Persistence of Inflation. Journal of Monetary Economics 19 (January): 3-24.

Baskin, J. 1988. The Development of Corporate Financial Markets in Britain and the United States, 1600-1914: Overcoming Asymmetric Information. Business History Review 62:199-237.

Benston, George J. 1989. The Separation of Commercial and Investment Banking: The Glass-Steagall Act Revisited and Reconsidered. Norwell, MA: Kluwer Academic.

Benveniste, Lawrence M., and Paul A. Spindt. 1989. How Investment Bankers Determine the Offer Price and Allocation of New Issues. Journal of Financial Economics 24 (October): 343-61.

Berle, Adolph, and Gardiner Means. 1932. The Modern Corporation and Private Property. New York: Macmillan.

Board of Governors of the Federal Reserve System. 1959. All Bank Statistics. Washington, D.C.: Board of Governors.

- 1976. Banking and Monetary Statistics, 1914-1941. Washington, D.C.: Board of Governors.

Bodenhorn, Howard. 1992. Capital Mobility and Financial Integration in Antebellum America. Journal of Economic History 52 (September): 585-610.

Boyd, John H., and Stanley L. Graham. 1986. Risk, Regulation, and Bank Holding Company Expansion into Nonbanking. Federal Reserve Bank of Minneapolis Quarterly Review 10 (spring): 2-17. 
1988. The Profitability and Risk Effects of Allowing Bank Holding Companies to Merge with Other Financial Firms: A Simulation Study. In The Financial Services Industry in the Year 2000: Risk and Efficiency, Proceedings of a conference on bank structure and competition, Chicago: Federal Reserve Bank of Chicago. 476-514.

Boyd, John H., Stanley L. Graham, and R. Shawn Hewitt. 1988. Bank Holding Company Mergers with Nonbank Financial Firms: Their Effects on the Risk of Failure. Federal Reserve Bank of Minneapolis Working Paper no. 417.

Brandeis, Louis D. 1914. Other People's Money and How the Bankers Use It. New York: Frederick A. Stokes.

Breckenridge, Roeliff M. 1899. Branch Banking and Discount Rates. Sound Currency 6 (January): 1-14.

Bremer, C. D. 1935. American Bank Failures. New York: Columbia University Press.

Brewer, Elijah. 1989. Relationship between Bank Holding Company Risk and Nonbank Activity. Journal of Economics and Business 41:337-53.

Brewer, Elijah, Diana Fortier, and Christine Pavel. 1988. Bank Risk from Nonbank Activities. Federal Reserve Bank of Chicago Economic Perspectives (JulyAugust): 14-26.

Brock, William A., and Blake LeBaron. 1990. Liquidity Constraints in ProductionBased Asset-Pricing Models. In Asymmetric Information, Corporate Finance, and Investment, ed. R. Glenn Hubbard, 231-56. Chicago: University of Chicago Press.

Brown, David T., Christopher James, and Robert M. Mooradian. 1991. The Information Content of Exchange Offers Made by Distressed Firms. Working paper, University of Florida, Gainesville.

Bureau of Business Research. 1928. Chicago as a Money Market. Bulletin 17, University of Illinois, Urbana.

Butters, J. Keith, and John Lintner. 1945. Effect of Federal Taxes on Growing Enterprises. Boston: Harvard University Press.

Cain, Louis P., and Donald G. Paterson. 1981. Factory Biases and Technical Change in Manufacturing: The American System, 1850-1919. Journal of Economic History 41 (June): 341-60.

Calomiris, Charles W. 1988. Price and Exchange Rate Determination during the Greenback Suspension. Oxford Economic Papers 40 (December): 719-50.

1989. Deposit Insurance: Lessons from the Record. Federal Reserve Bank of Chicago Economic Perspectives (May-June): 10-30.

- 1990. Is Deposit Insurance Necessary? A Historical Perspective. Journal of Economic History 50 (June): 283-95.

1991a. Comment on "Information Problems and Banks' Specialization in Short-Term Commercial Lending: New England in the Nineteenth Century." In Inside the Business Enterprise: Historical Perspectives on the Use of Information, ed. Peter Temin, 195-203. Chicago: University of Chicago Press.

199lb. Do Vulnerable Economies Need Deposit Insurance? Lessons from U.S. Agriculture in the 1920s. In If Texas Were Chile: A Primer on Bank Regulation, ed. Philip L. Brock, 237-349, 450-58 (Washington, D.C.: Sequoia Institute).

- 1993. Regulation, Industrial Structure, and Instability in U.S. Banking: An Historical Perspective. In Structural Change in Banking, ed. Michael Klausner and Lawrence J. White, 19-116. Homewood, IL: Business One-Irwin.

Calomiris, Charles W., and Gary Gorton. 1991. The Origins of Banking Panics: Models, Facts, and Bank Regulation. In Financial Markets and Financial Crises, ed. R. Glenn Hubbard, 33-68. Chicago: University of Chicago Press.

Calomiris, Charles W., and R. Glenn Hubbard. 1994. Internal Finance and Investment: Evidence from the Undistributed Profits Tax of 1936-1937. Working paper, University of Illinois, Urbana-Champaign.

Calomiris, Charles W., and Charles M. Kahn. 1990. The Efficiency of Cooperative In- 
terbank Relations: The Suffolk System. Working paper, University of Illinois, Urbana-Champaign.

- 1991. The Role of Demandable Debt in Structuring Optimal Banking Arrangements. American Economic Review 81 (June): 497-513.

Calomiris, Charles W., Charles M. Kahn, and Stefan Krasa. 1992. Optimal Contingent Bank Liquidation under Moral Hazard. Working paper, University of Illinois, Urbana-Champaign.

Calomiris, Charles W., and Daniel M. G. Raff. 1993. The Evolution of Market Structure, Information, and Spreads in American Investment Banking. Working paper, University of Illinois, Urbana-Champaign.

Calomiris, Charles W., and Larry Schweikart. 1991. The Panic of 1857: Origins, Transmission, and Containment. Journal of Economic History 51 (December): 807-34.

Calomiris, Charles W., and Eugene N. White. 1994. The Origins of Federal Deposit Insurance. In The Regulated Economy: A Historical Approach to Political Economy, ed. Claudia Goldin and Gary Libecap, 145-88. Chicago: University of Chicago Press.

Campbell, Tim, and William Kracaw. 1980. Information Production, Market Signalling, and the Theory of Financial Intermediation. Journal of Finance 35 (September): 863-81.

Carlson, W. Bernard. 1991. Innovation as a Social Process: Elihu Thomson and the Rise of General Electric, 1870-1900. Cambridge: Cambridge University Press.

Carosso, Vincent P. 1970. Investment Banking in America. Cambridge: Harvard University Press.

Chandler, Alfred D., Jr. 1977. The Visible Hand: The Managerial Revolution in American Business. Cambridge: Harvard University Press.

Chapman, John M. 1934. Concentration of Banking: The Changing Structure and Control of Banking in the United States. New York: Columbia University Press.

Cohan, Avery B. 1961. Cost of Flotation of Long-Term Corporate Debt since 1935. Research Paper 6, School of Business Administration, University of North Carolina.

Creamer, Daniel, and Israel Borenstein. 1960. Capital and Output Trends in Manufacturing and Mining. In Capital in Manufacturing and Mining: Its Formation and Financing, ed. Daniel Creamer, Sergei P. Dobrovolsky, and Israel Borenstein, 3-108. Princeton: Princeton University Press.

Davis, Lance E. 1957. Sources of Industrial Finance: The American Textile Industry: A Case Study. Explorations in Entrepreneurial History 9:190-203.

__ 1960. The New England Textile Mills and the Capital Markets: A Study of Industrial Borrowing, 1840-1860. Journal of Economic History 20: 1-30.

De Long, J. Bradford. 1991. Did Morgan's Men Add Value? In Inside the Business Enterprise: Historical Perspectives on the Use of Information, ed. Peter Temin, 20536. Chicago: University of Chicago Press.

Deutsche Bundesbank. 1976. Deutsches Geld- und Bankwesen in Zahlen, 1876-1975. Frankfurt: Deutsche Bundesbank.

Diamond, Douglas. 1984. Financial Intermediation and Delegated Monitoring. Review of Economic Studies 51 (July): 393-414.

. 1991. Monitoring and Reputation: The Choice between Bank Loans and Directly Placed Debt. Journal of Political Economy 99 (August): 689-721.

1992. Bank Loan Maturity and Priority When Borrowers Can Refinance. Working paper, Graduate School of Business, University of Chicago.

Dobrovolsky, Sergei P., and Martin Bernstein. 1960. Long-Term Trends in Capital Financing. In Capital in Manufacturing and Mining: Its Formation and Financing, ed. Daniel Creamer, Sergei P. Dobrovolsky, and Israel Borenstein, 109-340. Princeton: Princeton University Press.

Doyle, William M. 1991. The Evolution of Financial Practices and Financial Structures 
among American Manufacturers, 1875-1905: Case Studies of the Sugar Refining and Meat Packing Industries. Ph.D. diss., University of Tennessee, Knoxville.

Dunlavy, Colleen. Forthcoming. Politics and Industrialization in Early Railroads in the United States and Prussia. Princeton: Princeton University Press.

Eistert, Ekkehard. 1970. Die Beeinflussung des Wirtschaftswachstums in Deutschland von 1883 bis 1913 durch das Bankensystem. Berlin: Duncker und Humblot.

Fazzari, Steven, R. Glenn Hubbard, and Bruce C. Petersen. 1989. Financing Constraints and Corporate Investment. Brookings Papers on Economic Activity, 114-95.

Field, Alexander. 1983. Land Abundance, Interest/Profit Rates, and NineteenthCentury American and British Technology. Journal of Economic History 42 (June): 405-31.

- 1987. Modern Business Enterprise as a Capital-Saving Innovation. Journal of Economic History 46 (June): 473-85.

Friend, Irwin. 1967. Over-All View of Investment Banking and the New Issues Market. In Investment Banking and the New lssues Market, ed. Irwin Friend, James R. Longstreet, Morris Mendelson, Ervin Miller, and Arleigh P. Hess, Jr., 1-79. New York: World Publishing Company.

Gale, Douglas, and Martin Hellwig. 1985. Incentive-Compatible Debt Contracts: The One-Period Problem. Review of Economic Studies 52 (October): 647-63.

Garber, Peter, and S. Weisbrod. 1991. The Economics of Money, Liquidity, and Banking. New York: D. C. Heath.

Gerschenkron, Alexander. 1962. Economic Backwardness in Historical Perspective: A Book of Essays. Cambridge: Harvard University Press.

Gilson, Stuart C., Kose John, and Larry H. P. Lang. 1990. Troubled Debt Restructurings. Journal of Financial Economics 27:315-53.

Goldsmith, Raymond W. 1955-56. A Study of Saving in the United States. Princeton: Princeton University Press.

- 1958. Financial Intermediaries in the American Economy since 1900. Princeton: Princeton University Press.

_ 1976. The National Balance Sheet of Germany, 1850-1972. Konjunkturpolitik 22:153-72.

1985. Comparative National Balance Sheets: A Study of Twenty Countries, 1688-1978. Chicago: University of Chicago Press.

Goldsmith, Raymond W., Robert E. Lipsey, and Morris Mendelson. 1963. Studies in the National Balance Sheet of the United States. Princeton: Princeton University Press. Gorton, Gary. 1985. Clearing Houses and the Origin of Central Banking in the U.S. Journal of Economic History 45 (June): 277-83.

1989. Self-Regulating Bank Coalitions. Working paper, University of Pennsylvania, Philadelphia.

Gorton, Gary, and James Kahn. 1992. The Design of Bank Loan Contracts, Collateral, and Renegotiation. Rochester Center for Economic Research Discussion Paper no. 327.

Gorton, Gary, and Donald Mullineaux. 1987. The Joint Production of Confidence: Endogenous Regulation and Nineteenth-Century Commercial Bank Clearinghouses. Journal of Money, Credit, and Banking 19 (November): 458-68.

Haven, T. Kenneth. 1940. Investment Banking under the Securities and Exchange Commission. Ann Arbor: University of Michigan Bureau of Business Research.

Hickman, W. Braddock. 1958. Corporate Bond Quality and Investor Experience. Princeton: Princeton University Press.

- 1960. Statistical Measures of Corporate Bond Financing since 1900. Princeton: Princeton University Press.

Hoffmann, Walther G. 1965. Das Wachstum der Deutschen Wirtschaft seit der Mitte des 19. Jahrhunderts. Berlin: Springer-Verlag. 
Homer, Sidney, and Richard Sylla. 1991. A History of Interest Rates. 3d ed. New Brunswick: Rutgers University Press.

Hoshi, Takeo, Anil Kashyap, and Gary Loveman. 1992. Lessons from the Japanese Main Bank System for Financial Reform in Poland. Working paper, Graduate School of Business, University of Chicago.

Hoshi, Takeo, Anil Kashyap, and David Scharfstein. 1990a. Bank Monitoring and Investment: Evidence from the Changing Structure of Japanese Corporate Banking Relationships. In Asymmetric Information, Corporate Finance, and Investment, ed. R. Glenn Hubbard, 105-26. Chicago: University of Chicago Press.

1990b. The Role of Banks in Reducing the Costs of Financial Distress. Journal of Financial Economics 27 (September): 67-88.

Huertas, Thomas, and Harold Cleveland. 1987. Citibank. Cambridge: Harvard University Press.

Hughes, Thomas P. 1983. Networks of Power: Electrification in Western Society, 1880 1930. Baltimore: Johns Hopkins University Press.

James, Christopher, 1987. Some Evidence on the Uniqueness of Bank Loans. Journal of Financial Economics 19:217-35.

James, Christopher, and Peggy Wier. 1988. Are Bank Loans Different? Some Evidence from the Stock Market. Journal of Applied Corporate Finance. 1:46-54.

- 1990. Borrowing Relationships, Intermediation, and the Cost of Issuing Public Securities. Journal of Financial Economics 28:149-71.

Japan Development Bank. 1994. Policy-Based Finance. World Bank Discussion Paper no. 221.

Jeidels, Otto. 1905. Das Verhältnis der deutschen Grossbanken zur Industrie, mit besonderer Berucksichtung der Eisenindustrie. Berlin: Schmollers Forschungen.

Jensen, Michael C., and William H. Meckling. 1976. Theory of the Firm: Managerial Behavior, Agency Costs, and Ownership Structure. Journal of Financial Economics 3:305-60.

Kaufman, George G., and Larry Mote. 1989. Securities Activities of Commercial Banks: The Current Economic and Legal Environment. Working paper, Federal Reserve Bank of Chicago.

___ 1990. Glass-Steagall: Repeal by Regulatory and Judicial Reinterpretation. Banking Law Journal (September-October): 388-421.

Kennedy, William, and Rachel Britton. 1985. Portfolioverhalten und wirtschaftliche Entwicklung im späten 19. Jahrhundert: Ein Vergleich zwischen Grosbritannien und Deutschland: Hypothesen und Spekulationen. In Beitrage zu quantitativen und vergleichenden Unternehmensgeschichte, ed. Richard H. Tilly. Stuttgart.

Kim, Sun Bae. 1992. Agency Costs and the Firm's Ownership Structure: The Japanese Evidence. Working paper, Board of Governors of the Federal Reserve System.

Kindleberger, Charles P. 1984. A Financial History of Western Europe. London: Allen and Unwin.

Klein, Benjamin. 1975. Our New Monetary Standard: The Measurement and Effects of Price Uncertainty. Economic Inquiry 13 (December): 461-84.

Kroszner, Randall S., and Raghuram G. Rajan. 1994. Is the Glass-Steagall Act Justified? A Study of the U.S. Experience with Universal Banking before 1933. American Economic Review 84 (September): 810-32.

Lacker, Jeffrey. 1991. Collateralized Debt as the Optimal Contract. Working paper, Federal Reserve Bank of Richmond.

Lamoreaux, Naomi R. 1991a. Bank Mergers in Late Nineteenth-Century New England: The Contingent Nature of Structural Change. Journal of Economic History 51 (September): 537-58.

- 199lb. Information Problems and Banks' Specialization in Short-Term Com- 
mercial Lending: New England in the Nineteenth Century. In Inside the Business Enterprise: Historical Perspectives on the Use of Information, ed. Peter Temin, 15495. Chicago: University of Chicago Press.

1994. Insider Lending: Banks, Personal Connections, and Economic Development in Industrial New England, 1784-1912. Cambridge: Cambridge University Press.

Litan, Robert E. 1985. Evaluating and Controlling the Risks of Financial Product Deregulation. Yale Journal on Regulation 3 (fall): 1-52.

- 1987. What Should Banks Do? Washington, D.C.: Brookings Institution.

Macaulay, Frederick R. 1938. Some Theoretical Problems Suggested by the Movements of Interest Rates, Bond Yields, and Stock Prices in the United States since 1856. Cambridge: National Bureau of Economic Research.

Mackie-Mason, Jeffrey K. 1990. Do Firms Care Who Provides Their Financing? In Asymmetric Information, Corporate Finance, and Investment, ed. R. Glenn Hubbard, 63-104. Chicago: University of Chicago Press.

Marquardt, Mary O. 1960. Sources of Capital of Early Illinois Manufacturers, 18401880. Ph.D. diss., University of Illinois, Urbana-Champaign.

Mayer, Colin. 1988. New Issues in Corporate Finance. European Economic Review 32 (June): 1167-89.

Meinster, David R., and Rodney D. Johnson. 1979. Bank Holding Company Diversification and the Risk of Capital Impairment. Bell Journal of Economics 10 (autumn): 683-94.

Mendelson, Morris. 1967. Underwriting Compensation. In Investment Banking and the New Issues Market, ed. Irwin Friend, James R. Longstreet, Morris Mendelson, Ervin Miller, and Arleigh P. Hess, Jr., 394-479. New York: World Publishing Company.

Miller, Ervin. 1967. Background and Structure of the Industry. In Investment Banking and the New Issues Market, ed. Irwin Friend, James R. Longstreet, Morris Mendelson, Ervin Miller, and Arleigh P. Hess, Jr., 80-175. New York: World Publishing Company.

Myers, Stewart C. 1977. Determinants of Corporate Borrowing. Journal of Financial Economics 5:147-75.

- 1984. The Capital Structure Puzzle. Journal of Finance 39:575-92.

Myers, Stewart C., and Nicholas Majluf. 1984. Corporate Financing and Investment Decisions When Firms Have Information That Investors Do Not Have. Journal of Financial Economics 13:187-221.

National Monetary Commission. 1910. Statistics for Great Britain, Germany, and France, 1867-1909. Washington, D.C.: GPO.

Neuburger, Hugh, and Houston H. Stokes. 1974. German Banks and German Growth, 1883-1913: An Empirical View. Journal of Economic History 34 (September): 710-32.

Peach, W. Nelson. 1941. The Security Affiliates of National Banks. Baltimore: Johns Hopkins University Press.

Pennacchi, George. 1983. Maturity Structure in a Model of Unregulated Banking. Working paper, University of Illinois, Urbana-Champaign.

Piore, Michael, and Charles F. Sabel. 1984. The Second Industrial Divide. New York: Basic Books.

Pozdena, Randall J. 1991. Is Banking Really Prone to Panics? Federal Reserve Bank of San Francisco Weekly Letter 91-35, 11 October.

Preston, H. H., and Allan R. Finlay. 1930a. Era Favors Investment Affiliates. Journal of the American Bankers Association 22 (June): 1153-54, $1191-92$.

. 1930b. Investment Affiliates Thrive. Journal of the American Bankers Association 22 (May): 1027-28. 1075. 
Prowse, Stephen D. 1992. The Structure of Corporate Ownership in Japan. Working paper, Board of Governors of the Federal Reserve System.

Rajan, Raghuram. 1992. Insiders and Outsiders: The Choice between Relationship and Arm's-Length Debt. Journal of Finance 47 (September): 1367-1400.

Ramakrishnan, R. T. S., and Anjan Thakor. 1984. The Valuation of Assets under Moral Hazard. Journal of Finance 39 (1): 229-38.

Ramirez, Carlos D. 1992. Financial Capitalism in the United States and Germany at the Turn of the Twentieth Century. Working paper, Harvard University.

Riefler, Winfield W. 1930. Money Rates and Money Markets in the United States. New York: Harper and Brothers.

Riesser, Jacob. 1911. The Great German Banks and Their Concentration, in Connection with the Economic Development of Germany. Translation of $3 \mathrm{~d}$ ed. Washington, D.C.: GPO.

Rockoff, Hugh. 1984. Some Evidence on the Real Price of Gold, Its Cost of Production, and Commodity Prices. In A Retrospective on the Classical Gold Standard, 18211931, ed. Michael D. Bordo and Anna J. Schwartz, 613-50. Chicago: University of Chicago Press.

Romer, Christina D. 1989. The Prewar Business Cycle Reconsidered: New Estimates of Gross National Product, 1869-1908. Journal of Political Economy 97 (February): $1-37$.

Schumpeter, Joseph A. 1939. Business Cycles: A Theoretical, Historical, and Statistical Analysis of the Capitalist Process. New York: McGraw-Hill.

Securities and Exchange Commission. 1940. Cost of Flotation for Small lssues, 19251929 and 1935-1938. Washington, D.C.: Securities and Exchange Commission.

-1941. Statistical Series Release no. 572, June.

- 1970. Cost of Flotation of Registered Equity Issues, 1963-1965. Washington, D.C.: Securities and Exchange Commission.

Selden, Richard T. 1963. Trends and Cycles in the Commercial Paper Market. NBER Occasional Paper no. 85. New York: National Bureau of Economic Research.

Sheard, Paul. 1989. The Main Bank System and Corporate Monitoring and Control in Japan. Journal of Economic Behavior and Organization 11:399-422.

Snowden, Kenneth A. 1990. Historical Returns and Security Market Development, 1872-1925. Explorations in Economic History 27 (October): 381-420.

Stigler, George J. 1971. The Theory of Economic Regulation. Bell Journal of Economics and Management Science 2 (spring): 1-2l.

Tilly, Richard H. 1966. Financial Institutions and Industrialization in the Rhineland, 1815-1870. Madison: University of Wisconsin Press.

- 1980. Banken und Industrialisierung in Deutschland: Quantifizierungsversuche. In Entwicklung und Aufgaben von Versicherungen und Banken in der Industrialisierung, ed. F. W. Henning, 165-93. Berlin: Duncker und Humblot.

- 1982. Mergers, External Growth, and Finance in the Development of LargeScale Enterprise in Germany, 1880-1913. Journal of Economic History 42 (September): $629-58$.

1984. Zur Finanzierung des Wirtschaftswachstums in Deutschland und Grosbritannien, 1880-1913. In Die Bedingungen des Wirtschaftswachstums in Vergangenheit und Zukunft, ed. E. Helmstadter, 263-86. Tubingen.

- 1986. German Banking, 1850-1914: Development Assistance for the Strong. Journal of European Economic History 15:113-52.

1992. An Overview of the Role of the Large German Banks up to 1914. In Finance and Financiers in European History, 1880-1960, ed. Youssef Cassis, 92-112 (Cambridge: Cambridge University Press).

Townsend, Robert. 1979. Optimal Contracts and Competitive Markets with Costly State Verification. Journal of Economic Theory 21 (October): 265-93. 
Trusk, Robert J. 1960. Sources of Capital of Early California Manufacturers, 1850 to 1880. Ph.D. diss., University of Illinois, Urbana-Champaign.

U.S. Department of Commerce. 1975. Historical Statistics of the United States: Colonial Times to 1970. Washington, D.C.: GPO.

Wall, Larry D. 1987. Has Bank Holding Companies' Diversification Affected Their Risk of Failure? Journal of Economics and Business 39 (November): 313-26.

Webb, Steven B. 1980. Tariffs, Cartels, Technology, and Growth in the German Steel Industry, 1879-1914. Journal of Economic History 40 (June): 309-30.

Whale, P. Barrett. 1930. Joint Stock Banking in Germany. London: Macmillan.

White, Eugene N. 1985. The Merger Movement in Banking, 1919-1933. Journal of Economic History 45 (June): 285-91.

- 1986. Before the Glass-Steagall Act: An Analysis of the Investment Banking Activities of National Banks. Explorations in Economic History 23 (January): 33-55.

Williamson, Oliver. 1980. Emergence of the Visible Hand. In Managerial Hierarchies, ed. Alfred D. Chandler and Herman Daems. Cambridge: Harvard University Press.

Williamson, Stephen D. 1986. Costly Monitoring, Financial Intermediation, and Equilibrium Credit Rationing. Journal of Monetary Economics 18 (September): 159-80.

Wright, Gavin. 1990. The Origins of American Industrial Success, 1879-1940. American Economic Review 80 (September): 651-68.

\section{Comment Peter Temin}

This is a good, ambitious paper. It is a good paper for this conference and volume because Calomiris has undertaken to analyze an important economic organization. It is ambitious because it argues that institutional arrangements are very, very important. The structure of the banking system, Calomiris asserts, affects the rate of economic growth, the composition of the capital stock, and-implicitly - the rate of productivity change in the economy as a whole.

Before I comment on how Calomiris gets to these conclusions and on the support he musters for them, I would like to place this paper in the context of this conference and its predecessor. That conference, which was reported in Inside the Business Enterprise: Historical Perspectives on the Use of Information (Chicago, 1991), dealt primarily with flows of information inside business organizations - through accounting, production reports, standardized information, and so forth. This conference has extended the concern with information to include the coordination of activity both within and between firms.

Calomiris emphasizes the importance of information flows in his paper. $\mathrm{He}$ argues that one of the primary roles of economic organizations is to control the flow of information. On the assumption that information flows more easily

Peter Temin is professor of economics at the Massachusetts Institute of Technology and a research associate of the National Bureau of Economic Research. 
within organizations than between them, Calomiris applauds the role of some large organizations, that is, universal banks. He does not assert that institutions all work equally efficiently or even that there is a tendency for the institutional control of information to become more efficient over time. He closes his paper with some thoughts on the political evolution of information-handling institutions.

Economists have paid increasing attention to the importance of information in recent years. Courses in advanced economic theory routinely spend much of their time detailing and analyzing the flow of information in different models. This research, expressed in the formal, mathematical terms beloved of economic theorists, is not very accessible to business historians. This clash of cultures gives rise to a problem of information flows in our disciplines that mirrors the problems we analyze.

Economic theorists express great interest in the work of business historians. They say that they are looking for examples of information flows to model in their theories. But these theories often do not feed back into business histories because they are hard to read and to apply. The historians assert that they deal with information flows all the time, that information is a critical part of management. But their expositions are not read much by economic theorists because they are not directed toward the questions posed by the theorists.

These conferences and volumes are designed to lessen the distance between these two groups. If business historians can learn how economists approach questions, they can present their narratives in ways that illuminate these problems. And if economic theorists learn more business history, they will find ample material to model.

Calomiris addresses this communication gap in his paper. He precedes his historical evidence with a description of the theoretical literature on the importance of information in banking. He provides a fine readers' guide to this literature for the interested business historian. This does not overcome the difficulty of reading abstract mathematical papers, but it is a start. In addition, Calomiris's history stays close to the questions raised in his theoretical overview, raising questions for economists interested in extending the theory.

While this explicit focus on information would be enough to make Calomiris's paper a fitting capstone for this volume, there is another connection to the preceding conference as well. The previous volume closes with two papers on banking. Lamoreaux argued that American commercial banks in the early nineteenth century provided investment funds, albeit primarily to the banks' directors. But as investments became geographically dispersed, making information about them costly, commercial banks gradually specialized in providing short-term trade credit. Commercial banks as we know them appeared only in the late nineteenth century. De Long analyzed the most famous of the private bankers who took over the role of providing industrial finance as the commercial banks abandoned this activity. He argued that the House of Morgan pro- 
vided a real economic benefit to the firms doing business with it. Morgan firms were worth more than similar firms without the Morgan connection.

Calomiris extends these papers by comparing the financial system described by Lamoreaux and De Long to that in Germany. While those two authors asked how the American banking system functioned at the turn of the twentieth century, Calomiris evaluates the turn-of-the-century banking system by comparing it with a structure that evolved quite differently. The intellectual links among these three papers are evident from Calomiris's frequent citations of the two earlier contributions. Taken together, the three papers on banking constitute a model of the kind of intellectual inquiry that these conferences and volumes are designed to foster.

Like Gaul, Calomiris's paper is divided into three parts. He opens with the theoretical discussion just noted. This is followed by a description of the American and German banking systems as seen through this theoretical lens. Finally Calomiris argues that the different banking structures in the two countries led to a variety of different experiences. He suggests that universal banks had effects that stretched from the composition of aggregate German investment to the way in which individual German firms were financed.

Calomiris centers his theoretical discussion on what he calls the "pecking order" of corporate finance. The term suggests a normative hierarchy, but the order seems rather to describe the stages that companies actually go through as they age. More precisely, Calomiris's pecking order describes the stages of growth that American companies generally experience; he argues that the order is not a general one. One function of business history is to reveal whether such patterns are universal or dependent on specific institutional arrangements. (The theoretical literature may emphasize the American experience because it is largely American.)

In this story, a nascent firm first gets capital from retained earnings and rich uncles. As the enterprise grows, it begins to compile a track record. This information allows it to borrow from banks. That is, the firm generates enough information to attract short-term, fixed-yield investments by local institutions. A bit farther down the path, the enterprise can obtain equity investment from knowledgeable people or specialized institutions. The reach of the information is not necessarily any wider, but the longer record encourages investors to provide capital on longer terms and without fixed repayment schedules. Investors cross the line between loans and equity investment.

If the enterprise continues to prosper and grow, it reaches a size where information about it becomes publicly available. The company then can sell bonds on a public market. There is enough information generally available for a variety of people and institutions to perform the lending function first undertaken by banks. With continued growth, the public at large becomes willing to cross the line between bonds and stocks, just as knowledgeable specialized investors were with the younger, smaller firm. The mature enterprise then has 
available to it the choice of raising capital by issuing publicly available bonds or stocks.

This pecking order describes how a business firm interfaces with financial institutions at various stages of its growth. The implied order of preference comes from the fact that the large, mature enterprise has a choice of funding sources because information about it is prevalent. The mature enterprise chooses the least costly form of finance-which we consider the most desirable.

This five-step process is presented as a logical exercise. It is the result of the expanding size of an enterprise in need of capital and the growing circle of people and organizations with enough information to consider supplying the company's needs. But this pecking order is hardly the only way for the capital needs of growing companies to be supplied. The second part of Calomiris's exposition is a description of how this pecking order emerged in the United States and how an alternative banking structure arose in Germany.

Instead of going through five distinct steps, German companies went through only two or three. Calomiris does not discuss the first step of insider financing very much, and we can leave it aside. Bank financing for small companies was present in both countries. In America, it was supplanted by equity funding, then bonds, then publicly traded stocks. In Germany, by contrast, bank lending continued throughout the life of the firm, obviating the middle steps in the pecking order. A capital-hungry enterprise went directly from bank credit to public stock.

Calomiris argues that the simpler German system economized on resources used to gather information. Fewer steps meant fewer people and institutions that needed to be informed. Continuity in the source of capital further meant that new organizations did not have to gather information each time a firm moved to the next stage.

Several questions arise about this argument. First, did less articulation necessarily reduce costs? Could it also have led to mismatches between supplying and demanding banks and firms, say, for intermediate-sized enterprises? Is it possible that German firms were starved for capital at some stage in their growth? Second, even if the American system was more costly, is part of the extra cost attributable to the larger size of the United States rather than to the American institutions? Phrased differently, would the concentrated German banking system have worked as well in the vast United States as it did in Germany? Third, did the concentration of German capital supplies in a few institutions encourage market power either in the financial or product markets? (Calomiris discusses the last question and says no.)

One of the important contributions of this paper is Calomiris's clear statement of the problem and the theory underlying it. The other is the extensive information he compiled to demonstrate the effects of the different banking systems. The third part of the paper contains a collection of empirical demonstrations. The variety of these "tests" is both a strength and a weakness: a 
strength because Calomiris has marshalled an impressive array of disparate data; a weakness because there is no indication that any single test is critical.

Calomiris opens his demonstration with aggregate data about Germany and the United States. He argues that the capital-output ratio in late-nineteenthcentury Germany, the share of equipment in the capital stock, and the growth of labor productivity were all higher in Germany.

These observations are consistent in the sense that a single view of German capital deepening can include them all. But it is not clear that the structure of the banking system can explain the per capita rate of capital accumulation. Demonstration of this point requires consideration of savings behavior as well of investment funds. Japan today appears to have both integrated banks and a high saving rate, but it is not usual to assert that the former is the cause of the latter. This is not to say it is not, only that the kind of data presented in Calomiris's paper cannot be used to test this hypothesis.

The key evidence in this paper to my mind is in tables 8.7 and 8.8 . There Calomiris presents estimates of the cost of issuing common stock in Germany and the United States. Unfortunately, only the German data refer to the period before World War I that is the focus of the paper; the American data are from the interwar period. Calomiris argues that American bankers' spreads in the issuance of stock were not rising over time and that the later data can be seen as a lower bound for the (unobserved) earlier figures. This implies that the banking restrictions of the 1930s did not raise financing costs. More work is needed to evaluate this implicit contention.

Calomiris argues that what he labels "mean bank spread" is a better indication of the organizational and informational costs of issuing stock in Germany than "mean total cost," which includes taxes and physical costs like printing. The "mean bank spreads" are less than 4 percent of the issue for most firms. These German costs are contrasted with the American data from the 1930s in table 8.8. The cost of issuing common stock in the United States was about 20 percent-or five times as high as the German cost!

This is a dramatic result. I have pointed out some potential problems with the data, but these caveats only serve to show how difficult it is to find the relevant information. Calomiris is to be congratulated for finding as much as he did and encouraged to follow this general paper with a more focused exploration of these costs.

If the data are even approximately correct, they indicate that the theoretical arguments surveyed by Calomiris in the early parts of the paper are very important indeed. Capital was much cheaper for enterprises at the last stage of the pecking order in Germany. The German Grossbanken clearly were able to place common stocks with far less trouble than the syndicates led by investment banks in the United States.

This conclusion raises a theoretical question about Calomiris's pecking order. He has exposed the costs of moving from step to step. But it is not clear from the theory that companies at the top of the pecking order should have had 
high costs. Firms at this level were larger and well known; why was information about them so scarce in the 1930s? Are we sure this scarcity was a result of the banking structure? Could it have been a reflection of conditions in the Depression or of other aspects of the economy?

The data imply that the German banks were not exercising market power in their commissions, despite their concentration. By contrast, the data do not indicate whether the large American spreads are the results of the information costs described by Calomiris or the market power alleged by many contemporary observers. They also do not say how large financing costs were at other stages of the pecking order. Calomiris suggests that the costs at the top of the order should be a lower bound to costs along the way, but a test of this proposition would enhance his argument.

Although this is the most important evidence that Calomiris marshals, his other evidence also will repay study. He provides several different approaches-examining corporate balance sheets, national balance sheets, and a variety of estimated costs of financing - to bolster his contention that financing costs were far cheaper in Germany than in the United States in the early years of the twentieth century. It is a tour de force.

It may be fitting to close with a statement of issues we need to keep in mind as we continue this exploration of the common ground between economic theory and business history.

This paper, in common with most essays in business history, has a largeorganization bias. Historians write about groups that leave records; business historians, about enterprises that succeed. This natural tendency shades into an implicit presumption that bigger is better. Alfred Chandler may be credited with providing intellectual justification for this presumption in manufacturing; Calomiris's theory does the same for banking. All these arguments may be correct, but their current popularity should make us always ask for proof.

In addition, this is a paper for the nineties. The American economy has its problems, and it is natural to find their roots in deep-seated malfunctions. A banking system that appears to have gotten steadily worse for a century or more is made to order for the current mood.

The explicit message of Calomiris's paper is that integration is needed when markets fail. The market failure in business financing comes from the high cost of information; an integrated bank that conserves information is the cure. The implicit message is even stronger: integration generally is better than the market. We must make very sure that we are not falling into a common attitude instead of examining each case on its merits.

Finally, this paper-like others in this volume-analyzes activities at the boundaries of business organizations. Too often we assume that activities internal to a firm are totally different from external processes, that there is a sharp break in information and other costs at the boundaries of corporations. These 
papers remind us that the boundaries themselves may be endogenous and that any discontinuity in the continuum of information costs at a company boundary may be specific to an industry. Calomiris argues forcefully in this paper that the discontinuity in banking is both large and important for the functioning of the entire economy. 
This Page Intentionally Left Blank 